Lurian Journal. 2020. Vol. 1, No. 2. P. 101-146.

DOI 10.15826/Lurian.2020.1.2.8

УДК 159.9:929

\title{
Luria in Kisegach. Part 2
}

\author{
Tatiana V. Akhutina \\ Natalia M. Pylaeva \\ Moscow State University named after M. V. Lomonosov, \\ Department of Psychology, \\ Moscow, Russia
}

\section{Лурия в Кисегаче. Часть 2}

\author{
Татьяна В. Ахутина \\ Наталия М. Пылаева \\ Московский государственный университет имени М. В. Ломоносова, \\ факультет психологии, \\ Москва, Россия
}

Corresponding author. E-mail:akhutina@mail.ru

\begin{abstract}
This is the second part of the article on the work and life of A. R. Luria in Kisegach, which presents the unique document The Work Diary. This notebook was used by him for daily records of patient studies. It is kept in the family archive of Luria. Comments on the Diary are written on the basis of his autobiographical book (Luria A. R., 1982; Cole, Levitin, \& Luria, 2006); the memoirs of his daughter, Elena Luria, in her book about her father (Luria E. A., 1994); as well as the memoirs of his colleagues. This part of the article publishes entries in the Diary from March 15 to November 13, 1942. The introduction to the records tells about the scientist's colleagues who worked with him in the hospital. These are such well-known psychologists as B. V. Zeigarnik, A. V. Zaporozhets, S. Ya. Rubinstein, E. S. Bein, O. P. Kaufman. The article explains the reason for the myth that during the war A. V. Zaporozhets worked only in the hospital in Kaurovka under the supervision of A. N. Leontiev. In this regard, we are talking about the Kharkov School of Psychology, the areas of work of L. S. Vygotsky, A. R. Luria and A. N. Leontiev in the years 1932-1934. In general, the article shows the intensive practical and theoretical work of the scientists in Kisegach hospital.
\end{abstract}

Keywords: A. R. Luria; neuropsychology; aphasia; war trauma; restoration of brain functions; Kharkov School of Psychology; L. S. Vygotsky; A. N. Leontiev; B. V. Zeigarnik; A. V. Zaporozhets; S. Ya. Rubinstein; E. S. Bein; O. P. Kaufman 
Аннотация. Это вторая часть статьи о работе и жизни А. Р. Лурия в Кисегаче, которая представляет уникальный документ «Дневник работы». Общая тетрадь с таким названием служила ученому для ежедневных записей о проведенных исследованиях больных. Она хранится в семейном архиве Лурия. Комментарии к «Дневнику» написаны по материалам его автобиографической книги (Luria A. R., 1982; англоязычное издание - Cole, Levitin, \& Luria, 2006), по воспоминаниям о Кисегаче его дочери Елены Лурия в ее книге об отце (Luria E. А., 1994), а также по воспоминаниям коллег. В данной части статьи впервые публикуются записи в «Дневнике» с 15 марта по 13 ноября 1942 г. Во введении к записям рассказывается о сотрудниках ученого, работавших с ним в госпитале. Это такие известные психологи, как Б. В. Зейгарник, А. В. Запорожец, С. Я. Рубинштейн, Э.С. Бейн, О.П. Кауфман. В статье разъясняется причина возникновения мифа, что в годы войны А. В. Запорожец работал только в госпитале в пос. Кауровка под руководством А.Н. Леонтьева. В связи с этим речь идет о харьковской школе психологии, о направлениях работы Л.С. Выготского, А. Р. Лурия и А. Н. Леонтьева в 1932-1934 гг. В целом статья показывает интенсивную практическую и теоретическую работу ученых в госпитале Кисегача.

Ключевые слова: А. Р. Лурия; нейропсихология; афазия; военная травма; восстановление мозговых функиий; харьковская школа психологии; Л. С. Выготский; А. Н. Леонтьев; Б. В. Зейгарник; А. В. Запорожеи; С. Я. Рубинштейн; Э. С. Бейн; О. П. Кауфман

The second part of the The Work Diary by A. R. Luria includes his records from March 15 till November 13, 1942. The following entries date back to 1943. The size of the records is smaller: the records for the first two months are almost as much as for the rest of 1942. There are no records from April 25 till June 20, and from July 27 till August 22. Luria departs for Moscow for 2 months and for Kazan almost for a month. There are also no entries from March 27 until April 15, from June 24 till July 1, and then again an interruption until July 14 .

Tamara Osipovna Ginevskaya, the wife of Alexander Vladimirovich Zaporozhets, explains one of the reasons for the short absences of A.R. Luria. At the request of Elena Luria she wrote memoirs about Luria:

This was a remarkable person - Luria! The complete absence of swagger, selfishness, he displayed readiness for self-sacrifice for the sake of business... For weeks, he was lying on the floor of the printing house in Chelyabinsk where his works were printed. There, he ruled, edited manuscripts, rode in a cart, sometimes arriving home for a day or two, no more. Weary and hungry. A bit of food and sleep - that was all his rest. While he was sleeping, Lana cleaned his suit, wondering how it hadn't fallen apart at all. It was all covered with hay, grass and dirt, just like Alexander Luria himself (Luria E. A., 1994, p. 101). ${ }^{1}$

\footnotetext{
${ }^{1}$ Lana - Lana Pimenova Lipchina, A. R. Luria’s wife.
} 
What works did T. O. Ginevskaya mean? In the list of Luria's works of 1942, there were two articles published in issues 1-2 and 4 of Neuropathology and Psychiatry but they were not published in Chelyabinsk. In the list of works of A. V. Zaporozhets, there was a brochure on The Methodology of Restorative Occupational Therapy for Injuries of Upper Limbs by A. V. Zaporozhets and S. Ya. Rubinstein with the subtitle The Administration of Hospitals in the Chelyabinsk Region, 1942. A. R. Luria was likely to edit various methodological letters, conference proceedings and collections of the works of the hospital staff in the Chelyabinsk region. ${ }^{2}$ There are similar materials from different regions on the Internet (see Figure 1). One might think that the exchange of experience was an important task for the staff of evacuation hospitals which Luria tried to perform. Of course, he was collecting materials for future publications. For these materials the Diary data was not enough.

If we compare the records about patient Karabanov (March 20-26) with his description in Traumatic Aphasia (Luria A. R., 1947, pp. 79-80 / 1970, pp. 180-181), we could see much more data in the book. This suggested that in addition to the diary, Luria kept other special records about certain patients. Some patients were described only in those special records. For instance, there were no records about patient Zas in the diary, the character and co-author of the book The Man with a Shattered World (Luria, 1971/1972), although Luria worked a lot with him.

In the diary, as in Traumatic Aphasia, Luria often mentions his colleagues who work with him in Kisegach. All of them deserve a special story.

Bluma Vulfovna Zeigarnik (1901-1988) was born in Lithuania. There she graduated from a female gymnasium and, preparing to enter the university, passed the exams for the broader curriculum of male gymnasiums. In 1919, she married Albert Ya. Zeigarnik.

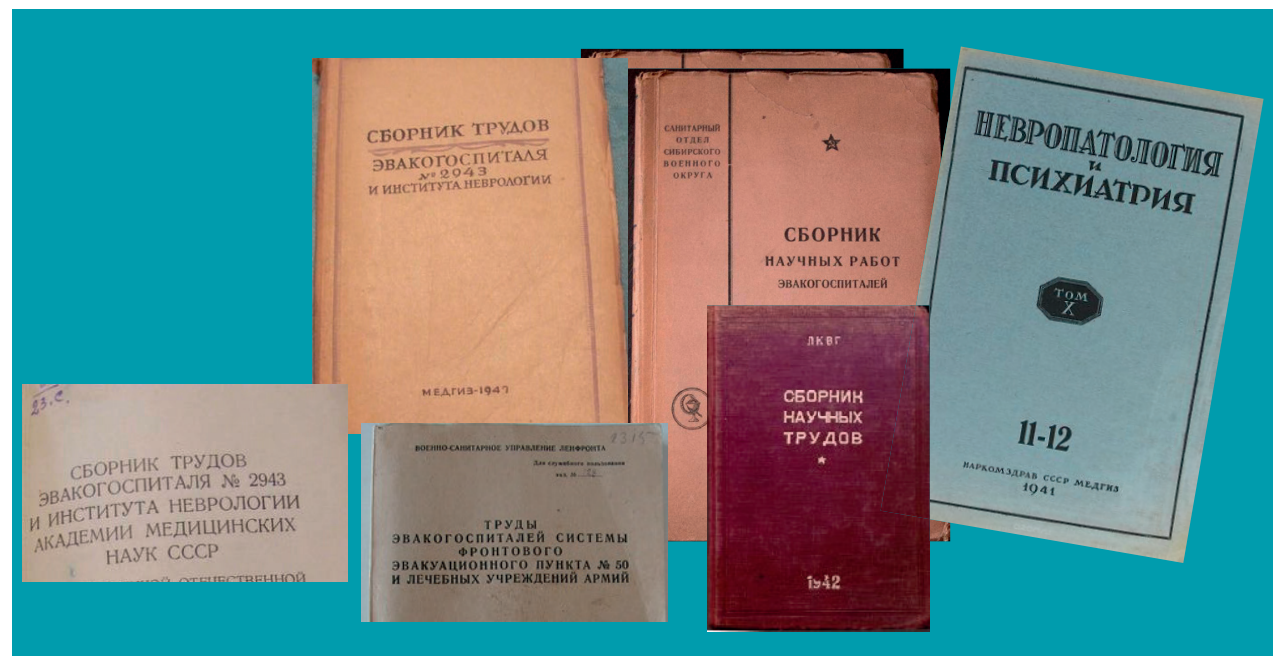

Figure 1. Publications of evacuation hospitals

${ }^{2}$ More than 80 evacuation hospitals worked in the Chelyabinsk region in 1942-1943 - according to archive74.ru evakogospitali_cho.pdf 
They went together to Germany to study. In 1922, Bluma entered the faculty of philosophy at the University of Berlin. There she was carried away by lectures of Kurt Levin. Under his supervision, she wrote a thesis Memorizing Completed and Uncompleted Actions. The article on this theme (Zeigarnik B., 1927) made B. Zeigarnik the world-famous author of The Zeigarnik Effect (see Figure 2).

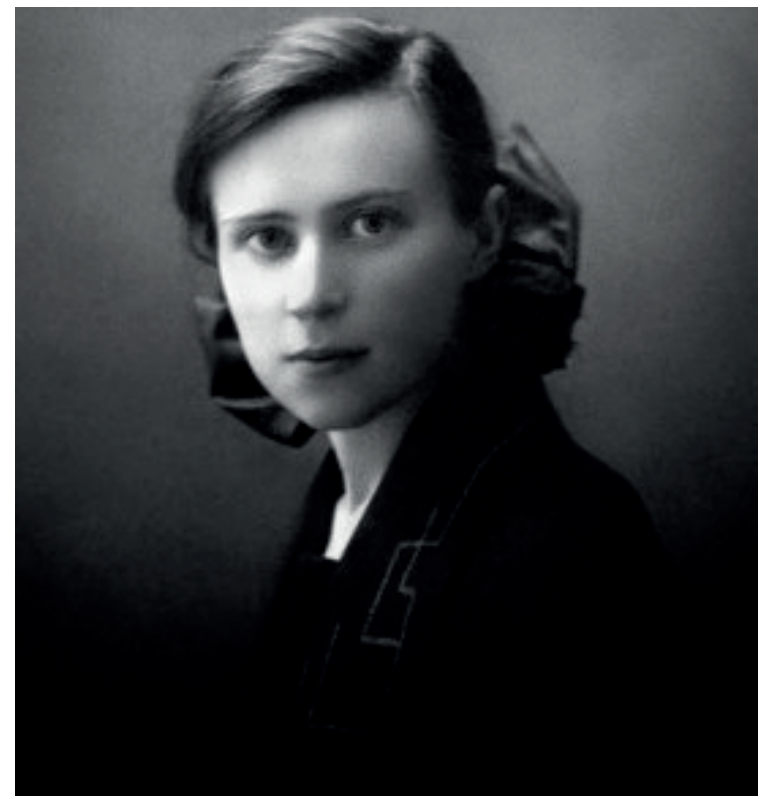

Figure 2. Bluma Zeigarnik. 1922

After graduating from the University (1925) and defending her thesis (1927), she worked at the University of Berlin as a freelance employee, and her husband at the Soviet trade office in Germany. In May, 1931, they moved to Moscow. B. Zeigarnik met L.S. Vygotsky ${ }^{3}$ through her fellow student at the University of Berlin, Gita Birenbaum, ${ }^{4}$ and made reports in the research group of Vygotsky on June 10 and 17 (Akhutina, 2012). In his letter of June 12-16 to A. R. Luria, L. Vygotsky wrote about the first report by B. Zeigarnik: "Well-done. Gracefully. Cleverly. A little from ladies' needlework. Quite in Lewin's style." Vygotsky worried about B. Zeigarnik's employment and noticed: "She wants where we are. The right idea: Birenbaum, she, Kazmina + we altogether are power" (Vygotsky, 2004, p. 27). In the same 1931, Bluma Zeigarnik began working as a research

${ }^{3}$ B. Zeigarnik met A. R. Luria earlier, in 1929. On his way to America to the IX International Psychological Congress, Luria stopped in Berlin and met with Levin and his students (Luria E. A., 1994, p. 44).

${ }^{4}$ Gita Vasilievna Birenbaum (1903-1952) was a psychologist and a member of Vygotsky's circle. In 1923-1925 and 1927-1930, she studied at the University of Berlin. Under the supervision of K. Levin, she wrote a well-known thesis about forgetting intentions (Birenbaum, 1930). On arriving in Moscow, she worked in the Institute of Higher Nervous Activity at the Communist Academy (later, The All-Union Institute of Experimental Medicine, AIEM). Then she worked in psychiatric clinics in Moscow (named after Solovyov), Ulyanovsk and Ryazan. 
fellow at the Institute of Higher Nervous Activity where G. V. Birenbaum was already working. Since 1932, it became a department of the All-Union Institute of Experimental Medicine (AIEM). In the "Donskaya" clinic of AIEM Zeygarnik and Birenbaum under the direction of L.S. Vygotsky conduct pathopsychological and neuropsychological work (see Birenbaum \& Zeygarnik, 1935; Nikolaeva \& Polyakov, 2016; Zavershneva \& Van der Veer, 2017, chapters 19 and 25; Zeygarnik, 1934; Zeygarnik \& Birenbaum, 1935).

In summer 1940, Bluma's husband was arrested on a charge of espionage. He was sentenced to ten years without the right of correspondence, which usually meant shooting. B. Zeigarnik stayed with two children one of whom was less than a year old and the other was six years old. After the arrest of her husband, she went often to Lubyanka ${ }^{5}$ to find out anything about his fate. There financial difficulties emerged. Alexander Romanovich Luria supported Bluma Zeigarnik both emotionally and financially. When the war began, he facilitated the appointment of B. V. (a Jewess, a wife of an enemy of the state, suspiciously fluent in German!) to the branch of the clinic of nervous diseases of the AIEM in Kisegach.

Elena Luria told about Kisegach that there was not enough food in winter 1941, and their family cooked soup of dried potatoes. It was even harder for B. Zeigarnik with two children. She was supported; first of all, by A. R. Luria and S. Ya. Rubinstein. Compare the photos of 1922 and 1942 (Figure 2 and 3) - they transmit the idea how harsh Bluma's life was better than words. But she encountered not only blows of fate but was blessed with its gifts as well! One may read this in her grandson's story, Andrey Zeigarnik (Zeigarnik A. V., 2001). The collaboration of Zeigarnik and Luria in Kisegach is also described by E. D. Homskaya (2001).

The working experience in the hospital was depicted in several articles by B. Zeigarnik during the war and post-war time (for instance, Zeigarnik B. V., 1943a, 1943b, 1947).

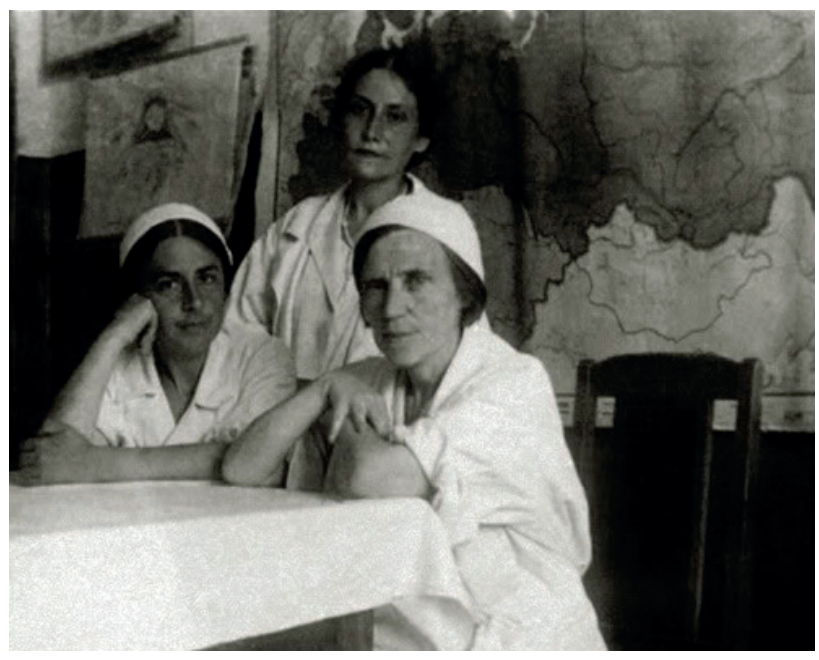

Figure 3. Bluma Zeigarnik (sitting to the right) and Esther Bein (sitting to the left) in Kisegach in 1942. The third person is unknown (Olga Kaufman?)

${ }^{5}$ Lubyanka is a common name for the NKVD/KGB/FSB building on the Lubyanskaya square. 
Both authors of these comments to The Work Diary were acquainted with B. V. Zeigarnik. She was a small, slim old woman (she never lectured from the pulpit because she would not be seen from there). Her lectures were perfect, she told much about Kurt Lewin and shared her love for her two teachers - Kurt Lewin and Lev Vygotsky. Students and staff reciprocated her, affectionately calling her "Blumochka." 6 One of the authors, Tatyana Vasilyevna Akhutina, has carefully preserved the book of Zeigarnik Pathopsychology dated 1976 that was presented by Bluma Zeigarnik and signed by her (see Figure 4).
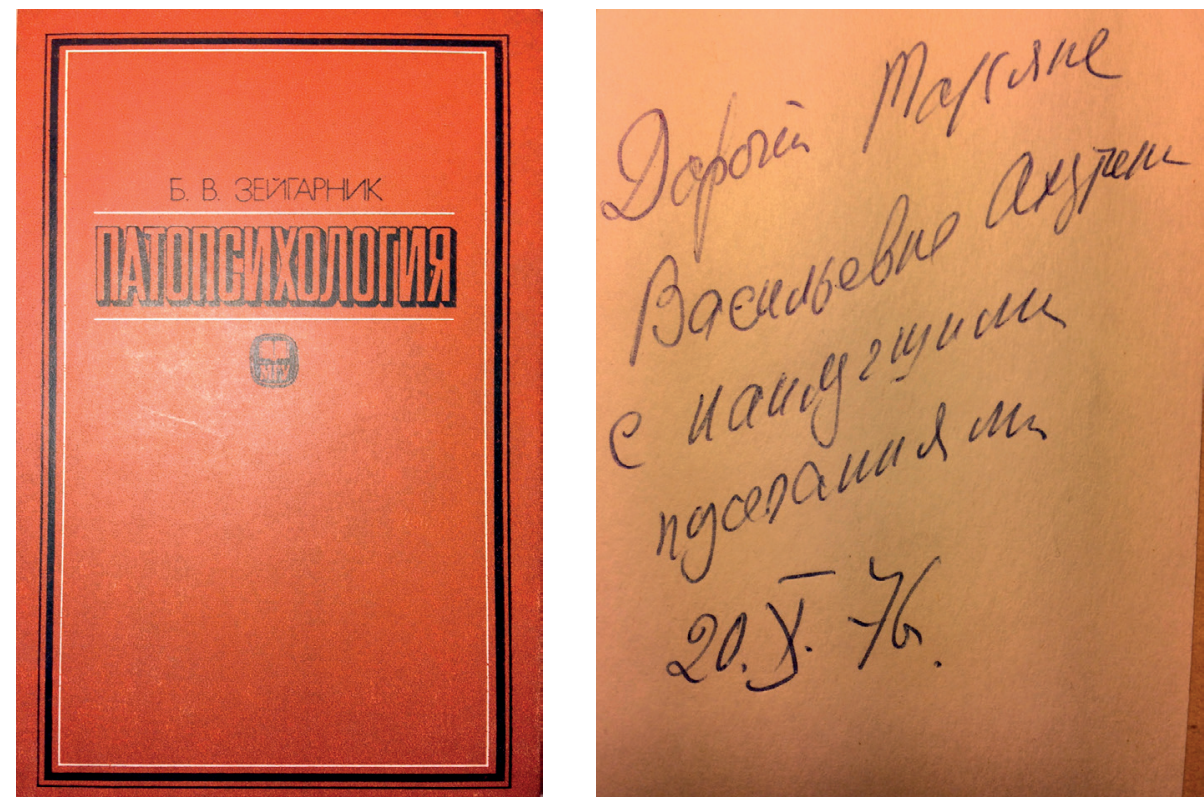

Figure 4. B. V. Zeigarnik's inscription on her book "Pathopsychology" (Abnormal Psychology) - “To Dear Tatyana Vasilievna Akhutina with best wishes” 20.X.76

Alexander Vladimirovich Zaporozhets (1905-1981), his wife and co-worker Tamara Osipovna (Iosifovna) Ginevskaya (1905-1992) were psychologists of Vygotsky circle. A.V. Zaporozhets was one of the famous "five"" students, the closest students of Vygotsky.

There is a myth about the work of Zaporozhets during the war which is widespread on the Internet and repeated in Wikipedia: "In 1941-1943, he worked at the experimental hospital for movements rehabilitation at the Institute of psychology (the Sverdlovsk region)" (“Zaporozhets Alexander Vladimirovich," 2020). It needs clarification: first, the hospital was not experimental; secondly, not for the rehabilitation of movements; thirdly, not one but two. The first hospital was at the AIEM (the Chelyabinsk region) and the second - at the Institute of Psychology (the Sverdlovsk region). Where did this long-lasting myth come from?

${ }^{6}$ Blumochka is a diminutive form of the name Bluma.

7 "The Five" was a group of students of the 2nd MSU: Lidia Bozhovich (1908-1981), Rosa Levina (19081989), Natalia Morozova (1906-1989), Lia Slavina (1906-1986) and Alexander Zaporozhets (1905-1981). 
Zaporozhets was born in Kiev. In his early youth, he was an artist and played in the Les Kurbas theatre. Since 1925, he studied at the 2nd Moscow State University (MSU) where he made friends with four classmate girls. Luria recalled the emergence of "the five":

At that time, I occupied the position of the head of the Psychology Laboratory at the Institute (Academy - T. A., N. P.) of the Communist Education named after N. K. Krupskaya. In order to attract University students to scientific work, I organized a student psychological circle, in which we discussed L.S. Vygotsky's ideas (Luria A. R., 1982, p. 33). ${ }^{8}$

A. V. Zaporozhets recalled that in the experiments fulfilled by "the five" under A. R. Luria's supervision, children at different ages (from pre-schoolers to adolescents) had to memorize a number of words with the help of a pictogram, that is, a graphic image of the memorized material. The analysis of age-related differences showed the transition from external to internal mediation of the memorization process (Zaporozhets, 1982, p. 14-15). Describing those experiments, Luria noted: "This colossal work has remained unpublished but it has given birth to much more important fruit - five first-class psychologists..." (Luria A. R., 2003, p. 272). In 1930, A. Zaporozhets graduated from the University, and at the end of 1931, he moved to Kharkov.

Tamara Ginevskaya described the moving and life in Kharkov:

The debate still flared up, and finally, Lev Semenovich was "killed," and his scientific school was defeated. Having found neither emotional nor material support a small group of Moscow scientists (Luria, Leontiev, Bozhovich and Zaporozhets) went, as it was said then, "on a long business trip." They moved to Kharkov - the capital of the Ukraine at that time - to a new psychoneurological clinic established by Professor Rokhlin at the psychiatric hospital. It was Vygotsky who negotiated the work in Kharkov...

We settled in a large apartment that Professor Rokhlin had rented for the Moscow community. For some time, we lived in it really all together: we, Luria, Bozhovich and Leontiev but soon, only Luria and us stayed there (there were two rooms)... (cited from the book by Luria E. A., 1994, p. 69; see also Ginevskaya, 2005) (see Figure 5). ${ }^{9}$

It is known that according to the contract, Luria and Leontiev had to be in Kharkov for 20 days each month, and the rest of the time they could live in Moscow. There, in May, 1933, Luria accidentally met Lana Pimenovna Lipchina after a three-year break. She be-

${ }^{8}$ Luria worked both at the Academy of Communist Education and at the 2nd MSU. Their buildings were opposite each other.

9 In his letters to Luria, Vygotsky wrote about the negotiations with Rokhlin about moving to Kharkiv (Vygotsky, 2004). In the fall of 1931, Vygotsky was approved as the head of the department of genetic psychology in the State Institute of personnel training of People's Commissariat of Healthcare of the Ukraine (Vygodskaya \& Lifanova, 1996, p. 129; Yasnitsky, 2008, p. 93). L. Vygotsky planned moving to Kharkov but the state of his health and responsibility for a large family (two daughters, the nephew, his wife, mother and sisters) were the reasons (perhaps, not the only ones) why Vygotsky could not do this. 


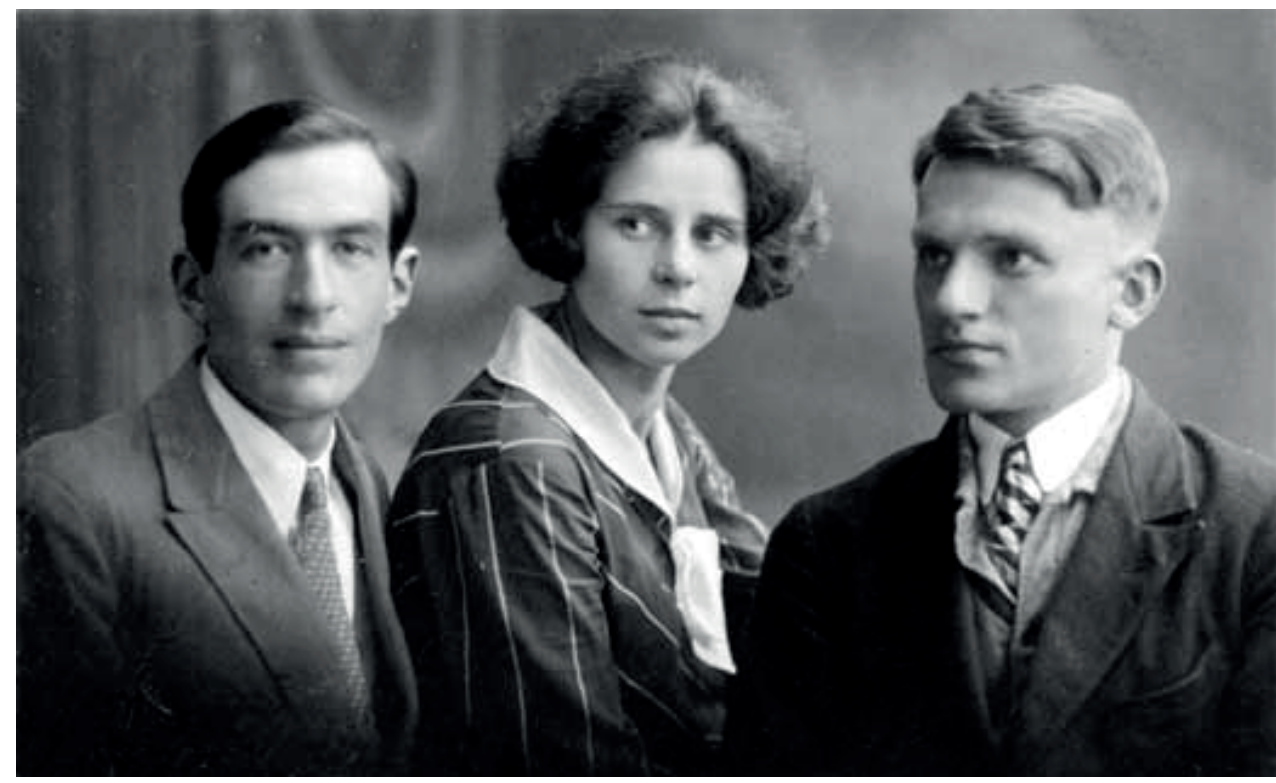

Figure 5. Alexey Leontiev, Lydia Bozhovich and Alexander Zaporozhets (the leaders of the Kharkov group — the early 30s)

came his wife in July. This event triggered his decision to leave for Moscow. In 1934, Luria and Leontiev returned to Moscow, the former — in March, and the latter — in October (Yasnitsky, 2008, p. 94).

A brief introduction into scientific developments in Kharkov. In 1932, L. S. Vygotsky delivered a report On the Plan of Works on Genetic and Clinical Psychology. Luria's transcript of the report is preserved in his archive. Vygotsky set the task of "studying higher psychological functions from a systemic point of view," and to solve this problem, Vygotsky suggested two ways: the analysis of "disintegration and genesis" (quoted from the article Akhutina, 2012, p. 9). At the same time, he concretised the principles of the analysis of disintegration, in essence, formulating the principles of the future neuropsychology (Ibid.). The object of the analysis was to be speech/language and non-verbal functions. Vygotsky focused on speech which was important to carry out another strategic plan the study of the dynamic semantic structure (or structure of senses) of consciousness. Implementing the plan for clinical psychology, Vygotsky and Luria entered the medical faculty of the Kharkov Psychoneurological Institute, combining full-time and distance learning. Luria worked intensively in the clinic in Kharkov, while Vygotsky examined and analysed patients in Moscow.

A. N. Leontiev put forward a different program. He accuses Vygotsky of "word-centrism" and contrasts this with the study of action and activity. Here is how he assessed the situation in Kharkov, dictating his autobiography to his son in 1976: "The confrontation of two lines towards the future. My line is a return to the original theses and their development in a new direction. The study of the action (= an object-related action)... Vygotsky's line is affective tendencies, emotions, feelings" (Leontiev, A. A., Leontiev, D. A., 
\& Sokolova, 2005, pp. 375-376). A bit earlier on that day, Leontiev spoke of Vygotsky: "The closure of all psychology to meaning. Crept out - aphasia, schizophrenia, theses on localization (neuropsychology), etc."10 (Ibid., p. 374). And he continued after: "The Kharkovites grouped around me, not A. Luria, since Bozhovich and Zaporozhets preferred working with me, and Galperin (local) was also reached out to me... A. Luria did not fit in the society in Kharkov" (Ibid., p. 375), see Figure 5.

In Kharkov, Zaporozhets became the closest assistant and friend of A. N. Leontiev. At the same time, according to V.P. Zinchenko:

Undoubtedly, A. V. Zaporozhets was also a leader but an inconspicuous and non-garish leader. He was a moral leader... Consciously or unconsciously, he kept a low profile. For example, only from A.N. Leontiev's notes to his text about the hypothesis of the genesis of the psyche and its experimental verification, I learned that the both things were made up together with A. V. Zaporozhets (Zinchenko, 2011, p. 367). ${ }^{11}$

In addition, in the preface to this book it is written that it was Zaporozhets who compiled the notes to it. It was the end of the 50s when Alexander Zaporozhets was already a distinguished scientist and the head of the laboratory but it was natural for him to offer that help. V.P. Zinchenko (2011) remarked "an infinite kindness" in A. V. Zaporozhets. K. M. Gurevich recalled about Alexander Zaporozhets: "You know, this is an exceptional person, absolutely exceptional... Always ready to do everything that is necessary to you, at the same time, he always [made it clear that] he was interested in that" (Leontiev A. A. et al., 2005, p. 255). ${ }^{12}$

We should note that the list of the themes by Zaporozhets in Kharkov included not only A. N. Leontiev's topics. On the one hand, these were The Study of the Meaning of the Function of the Practical Activity of the Child (co-authored with P. I. Zinchenko) and Preverbal Forms of Thinking. And on the other hand, these were The Development of Reasoning in the Child (co-authored with G. D. Lukov), The Semic Analysis of Children's

10 "Crept out" - this was said about the last work of Vygotsky, his neuropsychological testament, the theses of the report Psychology and Localization of Mental Functions (Kharkov, 1934)! A bright representative of the Kharkov group, L.I. Bozhovich, expressed another opinion about this direction of Vygotsky's work. Her main problem was the development of personality (for her biography, find Gutkina, 2008). In her last article, she wrote that the study of the problems of underdevelopment and disintegration had allowed Vygotsky to approach the concept of Psychological Systems. She claimed: “...in essence, L. S. Vygotsky has overcome the crisis in psychology through studying the genesis and structure of higher mental functions and creating a method for studying them" (Bozhovich, 1988, p. 108).

${ }_{11}$ Zinchenko spoke about the book by A. N. Leontiev Problems of the Development of the Mind (1959/1965), for which the author was awarded with the Lenin prize in 1963. In a footnote (1959/1965, p. 50), A. Leontiev wrote: “...the hypothesis about the genesis and nature of sensitivity was developed by the author jointly with A.V. Zaporozhets (1936)."

${ }^{12}$ Kindness also distinguished L.S. Vygotsky. To the question of G. L. Vygodskaya about her father, what personality trait would you single out, A. R. Luria answered: "His mind. Genius," D. B. Elkonin — "Kindness. Breadth. Scientific generosity," A. V. Zaporozhets - "Nobility. High morality. Delicacy," N. G. Morozova "A characteristic feature of Lev Semenovich was his desire to help" (Vygodskaya \& Lifanova, 1996, p. 160). 
Speech, and The Semic Analysis of Language Meanings Acquired at School (co-authored with V.I. Asnin) (see Galperin, 1934; Yasnitsky, 2008). The term semic analysis was used by A. R. Luria in the 1930s but it was introduced into active use by Vygotsky. On December 5, 1932, Vygotsky gathered his students for an "internal conference" and made the famous report on The Problem of Consciousness. In its conclusion, he said: "The semic analysis is the only adequate method for the study of the systemic and semantic structure of consciousness" (Vygotsky, 1997, p. 137 / 1982, p. 166). We learned from L. S. Vygotsky's Notebooks that on the eve of the main report, Vygotsky invited Luria, Leontiev and "the five" to The Symposium - On the Prospect of Our Research (Zavershneva \& Van der Veer, 2017). Vygotsky's records preserved the plan of his report including the rationale of "the necessity for a new stage of the research" and his notes during the discussion, i. e., the schemes of the response to each participant. Thus, Vygotsky cared about their further joint work. The report on December 5 lasted seven hours with a two-hour break; the discussion took another day, December 9.

A. N. Leontiev in his oral autobiography said: "The apogee of discord - 1932 (after the report), the beginning of 1933" (Leontiev A. A. et al., 2005, p. 376).

In summer 1934, Vygotsky died. And this event changed the evaluation of the similarity and discord. The differences in the positions of L. S. Vygotsky and A.N. Leontiev which seemed "terribly" fundamental, turned out to be not that serious within the time perspective. Vygotsky understood this before, he tried to gather all his students at AIEM's when this opportunity occurred in January 1934. This was also understood by Leontiev, who in 1977, speaking about Vygotsky, admitted: "The alternative of 1930-1931 was not an alternative but a necessary line of the movement of the psychological research. Not Either-Or, but necessarily And-And" (Ibid., 2005, p. 48). It was claimed in 1977, but the simplified cliché "The Kharkov school is Leontiev, and Zaporozhets is Leontiev's alter ego" is still reflected in literature. So, the myth about one hospital grew out of a more general myth about the Kharkov period of life of A. V. Zaporozhets. Let's consider his work in hospitals.

Neurosurgical evacuation hospital No. 3120 in Kisegach began working in August 1941. It provided facilities for a clinic of nervous diseases of the AIEM, director N. I. Grashchenkov. A. R. Luria, A. V. Zaporozhets, S. Ya. Rubinstein took part in its establishment, in particular, in the organisation of labour workshops. Later, S. G. Gellerstein, ${ }^{13}$ B. V. Mitlina and others joined the work on occupational therapy (Zeigarnik \& Rubinstein, 1982). The first important results in the rehabilitation of movements and working ability were described in the brochure of A.V. Zaporozhets and S. Ya. Rubinstein The Method of Restorative Occupational Therapy for Injuries of Upper Limbs (1942, p. 28).

From Luria's The Work Diary, it was clear that on March 18, 1942, he had a conversation with Zaporozhets. They discussed "the concept of the rehabilitation role of compensation." After these words, Luria put two exclamatory marks.

${ }^{13}$ S. G. Gellerstein (1896-1967) - Dr. in Biology, Professor, one of the founders of the Soviet Psychology and Psychophysiology of Work. 
Let us move on to the hospital in Kaurovka where A. V. Zaporozhets worked with A. N. Leontiev. In the chronicle of Moscow State University dated 1942 and published in the newspaper of the Moscow University in May 2004, one might read: "September 6. A Rehabilitation clinic at the Research Institute of Psychology of the Moscow State University was established in hospital 4003. The clinic aimed at developing therapeuticpedagogical methods of the correction of motor and sensory defects as a result of military injuries... Professor A. N. Leontiev was appointed as Director" (Chronicle of 1942, 2004). ${ }^{14}$

Zaporozhets revealed his attitude to the moving to Kaurovka in his letter to A. N. Leontiev dated 6.11.1942:

These days I work very productively (contrary to reason). I have finished a brochure on the rehabilitation training and thought up some interesting things about the principles of the rehabilitation and about the structure of voluntary action. I will tell you when we meet... Has anything been undertaken about Danya (D. B. Elkonin)? I really want to be together. I hope it will be soon (see Sokolova, 1995, p. 8).

It is not known when Zaporozhets and Ginevskaya moved to Kaurovka. It was not earlier than October 1942 (see the letter above) and not later than February 13, 1943 according to the record in A. N. Leontiev's diary with the mention of Ginevskaya and Zaporozhets (Leontiev A. A. et al., 2005, p. 362). Zaporozhets returned to Moscow in the autumn of 1943 where he was invited by A. N. Leontiev to work at the Institute of Psychology at the Moscow State University. A. N. Leontiev left Kaurovka in the summer of 1943 (Leontiev A. A. et al., 2005, p. 48).

The book by A.N. Leontiev and A. V. Zaporozhets The Rehabilitation of Movement: The Study of the Hand Function Rehabilitation After Injury was prepared in a short time and published in 1945 with a circulation of ten thousand copies (Luria's Traumatic Aphasia edition of four thousand copies). A.V. Zaporozhets wrote six chapters of this book (chapters 4-9) out of ten. The footnote on page seven read: "A. R. Luria was the initiator to organize this work [the development of the theoretical basis of rehabilitative functional methods]. He was the first in the Soviet Union to raise psychological issues of the rehabilitation of functions after injury" (1945/1960). Chapter 5 described the dynamics of movement rehabilitation in patients "in two rehabilitation hospitals": in 60 patients from Kaurovka and 25 patients from Kisegach (1945/1960, pp. 108-109). The list of references included an article by Zaporozhets and Rubinstein about occupational therapy (1942). Later, the same authors wrote the article Psychophysiological Issues of the Organization of Restorative Occupational Therapy (1947).

${ }_{14}$ The hospital number was incorrect in the chronicle. The right number EG 4003 was found in the documents of P. Ya. Galperin and published by M. A. Stepanova (2017). Galperin worked there from February to October 1943. 
Tamara Ginevskaya accompanied her husband in Kharkov, Kisegach, and Kaurovka. We know that she was a laboratory assistant in Kharkov and senior laboratory assistant in Kaurovka. After the war, she worked in the laboratories of Leontiev and Zaporozhets. A. N. Leontiev in his oral autobiography recalled that the collection of works of the Kharkov School, scattered after the decree on Pedology in 1936, had included "Ginevskaya's investigations on the distinction of the genetic and semantic centres of the drawing which explicated and documented the presence of the analysis of activity (action, goal)" (Leontiev A. A. et al., 2005, p. 377). In 1941, a similar article was published in Ukrainian in the Scientific notes of the Chernivtsi Pedagogical Institute. In Kaurovka, T. Ginevskaya and P. Ya. Galperin studied the dependence of the range of movements upon the psychological nature of the task. The authors showed that the change of the task might cause "a drastic and unexpected increase in the efficiency of the movement... due to the change in the psychological structure of the task" (Galperin \& Ginevskaya, 1947, p. 79). Together with A.N. Leontiev, she explored the sensitivity of an injured hand, and then continued this theme in the genetic aspect. Tamara Ginevskaya's memories about Zaporozhets and his colleagues are very important for the history of psychology (2005).

Susanna Yakovlevna Rubinstein (1911-1988) was a well-known psychologist, one of the founders of the Russian pathopsychology (abnormal psychology). S. Ya. Rubinstein was born in Odessa; her mother taught mathematics in the male gymnasium; it was rare in those times. The father's profession was unknown, and biographers wrote that he had been a respected man in Odessa who performed functions similar to those of a magistrate (justice of the peace) (Zvereva, 2012). Right after leaving the school, sixteen-yearold Susanna left for Moscow and entered the pedagogical faculty of the 2nd MSU. After graduating from the University, S. Ya. Rubinstein engaged in research and development of the psychological basis for professional selection and vocational guidance. In 1938, he entered the graduate school at the All-Union Institute of Experimental Medicine, in which A. R. Luria became her scientific supervisor. At that time, B. V. Zeigarnik worked in the Institute clinic; she became a close friend and instructor of S. Rubinstein for a lifetime. Owing to Luria and Zeigarnik, the young graduate student deepened her understanding of Vygotsky's ideas ${ }^{15}$ that became a basis for her further scientific path.

In summer 1940, Bluma Zeigarnik's husband was arrested on a charge of espionage. Describing the difficult time after the arrest of A. Ya. Zeigarnik, grandson of A. Ya. and B. V. Zeygarnik, Andrey, wrote:

I would like to mention here Alexander Luria, who at that time and many years later in every possible way supported and helped Bluma Zeigarnik, as well as her closest friend Susanna Rubinstein. Her support, no matter how arrogant it may sound, is today perceived as a feat.

${ }^{15}$ S. Ya. Rubinstein recalled in 1988: "I happened to listen to his lectures (Vygotsky) as a student and to be present at the discussions (analyses) of children. Charm and erudition combined in his speech with the simplicity and accessibility of presentation" (Vygodskaya \& Lifanova, 1996, p. 251). 
This courageous person was not only afraid to accompany Bluma to Lubyanka, but also offered to go there instead. Very few were ready to take such a risk (Zeigarnik A. V., 2001, p. 186).

Then many were afraid even to say hello to relatives of "enemies of the people" (see Figure 6).

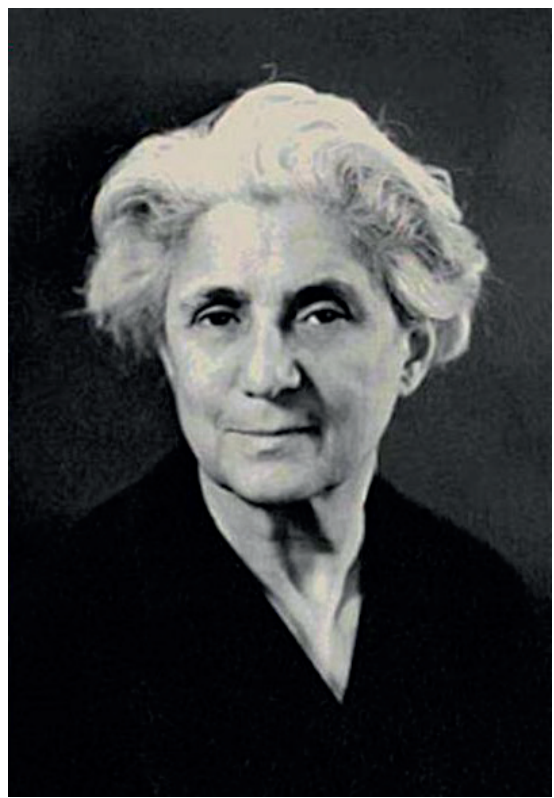

Figure 6. Susanna Yakovlevna Rubinstein (the 60s)

In 1941, when the Great Patriotic War began, A. R. Luria invited S. Ya. Rubinstein (and B.V. Zeigarnik) to go to Kisegach. There she took part in the establishment of labour workshops and gave training classes to patients. We presented the memoirs of B. V. Zeigarnik and S. Ya. Rubinstein about this time in the preface to the first part of our publication. Together with A.V. Zaporozhets Susanna Rubinstein developed methodological recommendations for the rehabilitation of movements in patients with brain lesions. The brochure about it was published in 1942 in Chelyabinsk. The professional experience of the war years was summarised by Susanna Rubinstein in her $\mathrm{PhD}$ thesis The Rehabilitation of Working Ability in Patients with Military Brain Injury (1945) and in some articles. For instance, in 1947, an article by Zaporozhets and Rubinstein Psychophysiological Issues of the Organisation of Restorative Occupational Therapy was published in the Scientific Notes of the MSU (Zaporozhets \& Rubinstein, 1947; see also Rubinstein, 1949).

The myth about the work of A. V. Zaporozhets only in Kaurovka touched also S. Ya. Rubinstein. Some wrote about her, that she also worked there. However, A. N. Leontiev listed all those who participated in the work under his guidance: Associate Professor A. V. Zaporozhets, Associate Professor P. Ya. Galperin, Senior Research Fellows of the Research Institute of Psychology A. G. Komm and Ya.Z. Neverovich, Senior Laboratory Assistant T. O. Ginevskaya, Associate Professor of the Sverdlovsk Pedagogical 
Institute V.S. Merlin, and the Hospital Employees Z. M. Zolina and Dr. E. D. Polykovsky (Leontiev \& Zaporozhets, 1945, p. 7-8).

After the war S. Ya. Rubinstein worked in the Laboratory of Pathopsychology at the Research Institute of Forensic Psychiatry named after Serbsky. In 1956, she participated in the establishment of one of the first psychological laboratories in the aerospace psychology under the guidance of K. K. Platonov. Since 1962, under the guidance of B. V. Zeigarnik, she worked in the Laboratory of Psychopathology of the Moscow Research Institute of Psychiatry of the Ministry of Healthcare of the RSFSR. In 1971, she defended her doctoral thesis on the problem of auditory hallucinations. In the seventies, she delivered lectures at the Lenin Moscow State Pedagogical Institute and Moscow State University. The methodological guide Experimental Methods of Pathopsychology (1970) of S. Ya. Rubinstein is still very popular among colleagues and students.

Esther Solomonovna Bein $\left(1906^{16}-1981\right)$ was a neuropsychologist, Dr. in Biology (in the field of Psychology), professor, a student and a friend of L.S. Vygotsky and A.R. Luria.

It is known from the Internet that in 1940 she finished research on constancy of the size perception in adults and children with impaired and normal hearing. The subjects had to determine the size of the object at different distances from the subject. Being detected that children with hearing impairment (as well as those who hear) had a constant perception of the size of objects that is clearly pronounced at the early school age.

During the war, E. S. Bein together with A. R. Luria participated in the development of the neuropsychology methods. She studied speech impairment in brain pathology; as a result, she worked out widely known methods of speech rehabilitation. The results were summarized in her doctoral thesis in biology (1949) on the problems of the psychological analysis of sensory aphasia and the ways to overcome it. For more than 40 years, she worked at the Research Institute of Neurology of the USSR Academy of Medical Sciences, was one of the founders of the rehabilitation department, led a group of neuropsychologists and speech therapists. During the last years, E. S. Bein was also a consultant in the Research Institute of Defectology of the USSR Academy of Pedagogical Sciences.

What is important to add to this information?

1. Among E.S. Bein's fellow defectologists, there were R.N. Vygodskaya, R. E. Levina, N.G. Morozova, Zh.I. Schif, ${ }^{17}$ i. e. L. S. Vygotsky's widow and three of his close students. They invited E. Bein to take part in the preparation of a volume on defectology for the collected works of Vygotsky. She engaged both in compiling the volume and in writing the afterword and notes (see Vygotsky, 1993/1983).

${ }^{16}$ E. S. Bein's birth year is often given incorrectly in the Internet.

17 Zh. I. Schif (1904-1978) worked as a teacher for seven years after graduating from the Leningrad Pedagogical Institute named after A. I. Herzen (1926). In 1930-1932, she studied at the graduate school of the same Institute, carried out investigations under the supervision of L.S. Vygotsky and defended her $\mathrm{PhD}$ thesis on The Development of Scientific Concepts in Schoolchildren (1934). In 1935, she published a book with the same title with the Preface by L.S. Vygotsky. In 1936, due to the eradication of pedology, she was deprived of her PhD (re-awarded in 1946). All the subsequent scientific activity of Zh. I. Schif was connected with the Research Institute of Defectology of the Academy of Pedagogical Sciences. 
2. As to the work in Kisegach, Luria's Traumatic Aphasia (1947/1970) showed that E.S. Bein was an active assistant of A. R. Luria in the development of the methods of the diagnosis and correction of aphasia. It was her who Luria referred to most often (11 times), mainly to the study of sensory aphasia and the development of the methods to overcome it. In The Diary in the record of 20.1.1942, Luria fixed the work with a patient with a severe temporal lobe syndrome and wrote after: "planning Bein's theme." One might think that there was no coincidence that the discussion of the scientific theme of Bein (the theme in the hospital and the thesis) happened after the examination of the patient with sensory aphasia. In 1947, she defended her thesis on The Psychological Analysis of Sensory Aphasia (referred to in her works and in Luria's books). Probably, later (in 1949 or 1950), she was awarded a doctorate taking into consideration the collection of her works.

3. For many years, E.S. Bein gave clinical workshops at the Lenin Moscow State Pedagogical Institute, introducing the rehabilitation of speech in patients with aphasia to future speech therapists. One of the authors of the present publication, T. V. Akhutina, attended those workshops. What do I remember? E. Bein gave us classes in the Institute of Neurology. On the wall of her study, there was a large portrait of L.S. Vygotsky; as I learned later, that was the original lifetime portrait. E. Bein herself was a middle-aged, plump woman, no longer very healthy and no longer very beautiful (but see her portrait in Figure 7). She gave lectures on aphasia in-depth and clearly. I still remember her words which I transmit to my students:

This is not so difficult to conduct efficient classes with patients with aphasia (all of us, students, pricked up our ears, we did not obviously expect this!). One needs to choose tasks which a patient manages to perform, without any mistakes, but will make an every effort.

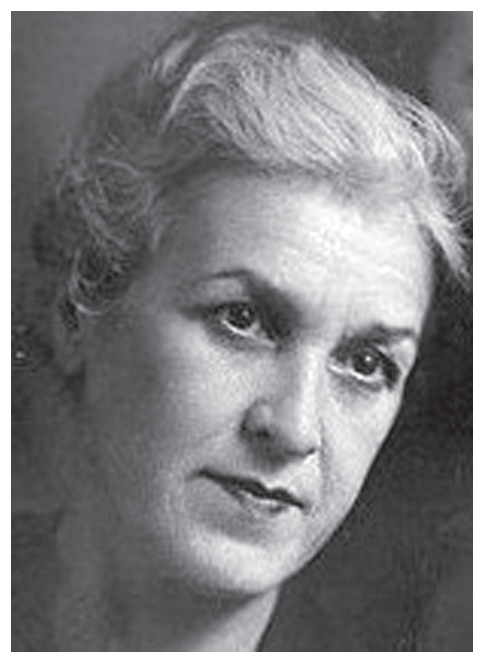

Figure 7. Esther Solomonovna Bein (the 50s) 
I always remember this advice given in 1962, when I tell students about the approach to rehabilitation put forward by Barbara Wilson - errorless learning (for instance, Wilson, Baddeley, Evans, \& Shiel, 1994).

When I began dealing with aphasia after my graduation, I got acquainted and made close friends with E.S. Bein's student, a speech therapist, Marianna Konstantinovna Shokhor-Trotskaya. ${ }^{18}$ Once I told her about my mother, Elena Nikolaevna Gruzintseva. My mother was a defectologist and graduated from the 2nd Moscow State University; she attended L. S. Vygotsky's lectures there, later she met with him, when working at the Institute of Defectology. She appreciated Vygotsky greatly, kept his books and the shorthand of his report, even though it was dangerous. A photograph of defectology professors with students is kept at our house - with L. S. Vygotsky and my mother in it. ${ }^{19}$ After this conversation, Marianna Shokhor-Trotskaya told me that for many years she had accompanied E. Bein (at her request) to Rita Noyevna Vygodskaya's house on the paydays where Vygotsky's widow had lived with two daughters. Being aware of the fact that her family experienced financial difficulties, E. Bein gave a part of her salary to Rita Vygodskaya. Once, on the way to the Vygodskys, E. Bein said: "If I had been in Moscow in 1934, Lev Vygotsky would not have died." M. Shokhor-Trotskaya did not ask any questions, E. Bein seemed to have said this phrase to herself.

At the end of life diseased Shokhor-Trotskaya made a great present to our Laboratory of Neuropsychology at Moscow State University. She presented us with L.S. Vygotsky's portrait that she had been keeping after E.S. Bein's death. Janna Markovna Glozman brought the portrait to the laboratory and it has been with us since then.

Olga Petrovna Kaufman was a psychologist and a co-worker of A.R. Luria in his laboratory at the AIEM. Together with A. R. Luria and E. S. Bein, she developed methods of the rehabilitation of speech and writing in Kisegach. There is a lack of data about O.P. Kaufman's publications even on the Internet. We managed to find only three links: two of them were in the post-war year of 1947. Due to another link we learned that at least until 1952 O. Kaufman worked at the Research Institute of Neurology of the USSR Academy of Medical Sciences in the Department of Psychophysiology and Pathology of the Brain Activity.

In Traumatic Aphasia A. R. Luria referred to her investigations nine times and noted that her two articles were being published or prepared for the publication. O. P. Kaufman studied motor aphasia (efferent and afferent) - in particular, speech comprehension in such patients. In 1947 and 1949, the article Restoration of the Speech Process in Motor Aphasia and the article about optical agraphy were published (Kaufman, 1947, 1949). The third article meant by Luria - Rehabilitation Training in Case of Semantic Aphasia was not found on the Internet. In 1952, the first study guide on the rehabilitation of speech in aphasia was developed in the Research Institute of Neurology of the USSR Academy

${ }^{18}$ M. K. Shokhor-Trotskaya ( $\left.\approx 1931-2002\right)$ was a well-known speech therapist, E. S. Bein's student and the author of numerous works on the rehabilitation of speech in aphasia.

19 That photo is reproduced of the book Lev Semyonovich Vygotsky (Vygodskaya \& Lifanova, 1996, p. 119). 
of Medical Sciences. It was the album The Rehabilitation of Speech Processes in Traumatic Aphasia compiled by E. S. Bein and O. P. Kaufman, and edited by Prof. A. R. Luria (Bein \& Kaufman, 1952). We learned this from M. K. Shokhor-Trotskaya's book The Strategy and Tactics of Speech Rehabilitation (2001) which reproduced this "perfectly illustrated album" on pages 167-173.

We are finishing the story of the psychologists who happened to be A. R. Luria's colleagues in Kisegach. A. N. Leontiev said about his peers: "You know, I get lucky with people. Take those who surround me - they are exceptional people" (the memoirs of K. M. Gurevich cited by Leontiev A. A. et al., 2005, p. 255). One might say the same about A. R. Luria's group in Kisegach. And this is no coincidence - after all, many of the friends were in common (see Figure 8, 9).

The Russian text of the Diary is presented in the Appendix.

In the text below, comments from the right pages appear immediately after the records to which they relate. There are many abbreviations in the text; all of the abbreviations are expanded in this publication. In obvious cases they are not specifically marked, but in the most difficult places the disclosure is given in [square] brackets. Illegible words are marked with <angle> brackets, and inserted words are in \{curly\} brackets. All of the author's underlines are preserved; a single underline is conveyed respectively, double underscores are passed in bold with underscores.

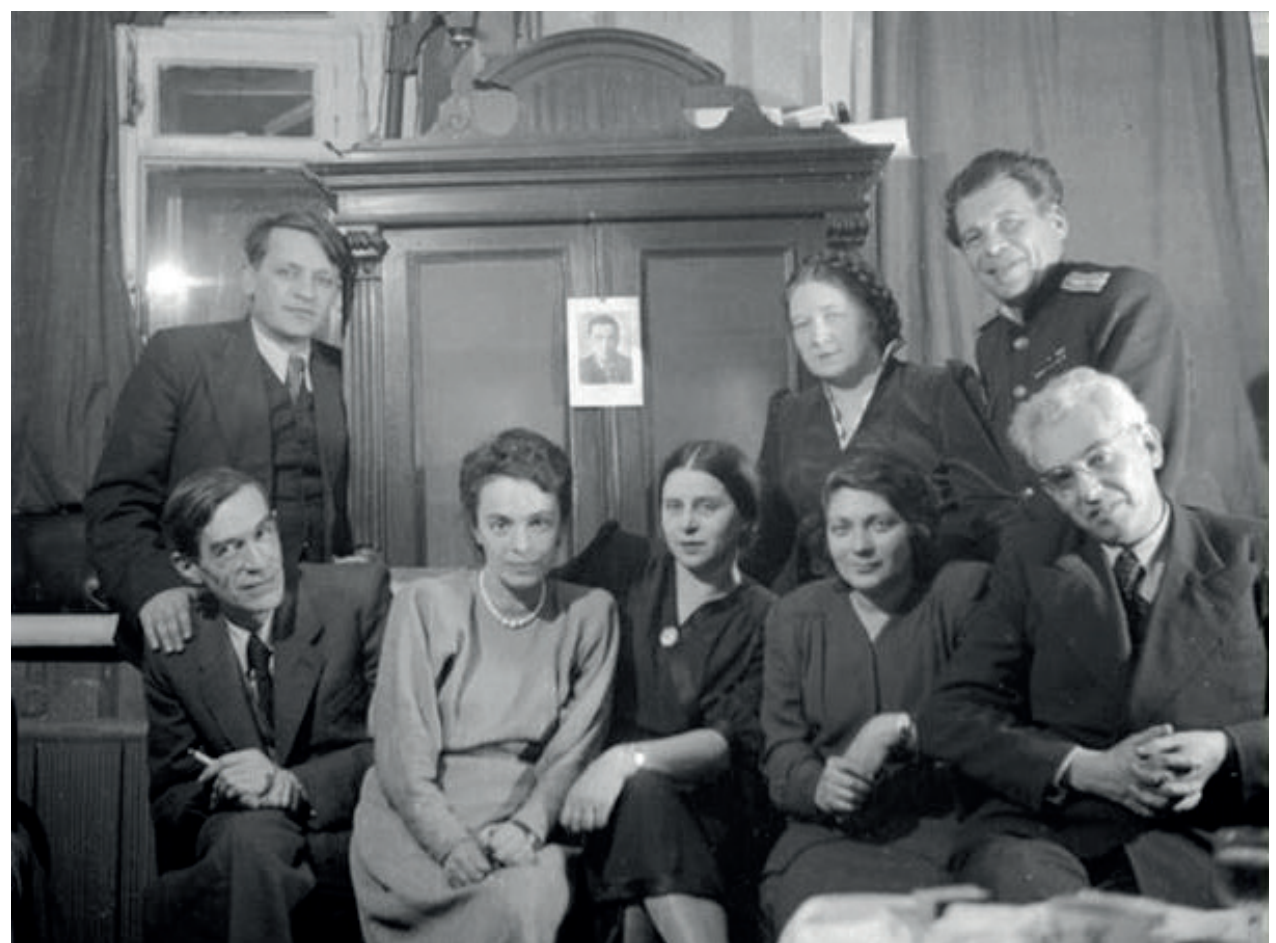

Figure 8. A. N. Leontiev, R. E. Levina, L. I. Bozhovich, L. S. Slavina, A. R. Luria (sitting), A. V. Zaporozhets, N. G. Morozova, D. B. Elkonin. Here we see A. R. Luria and A. N. Leontiev, "the five" and D. B. Elkonin against the background of the teacher's portrait 


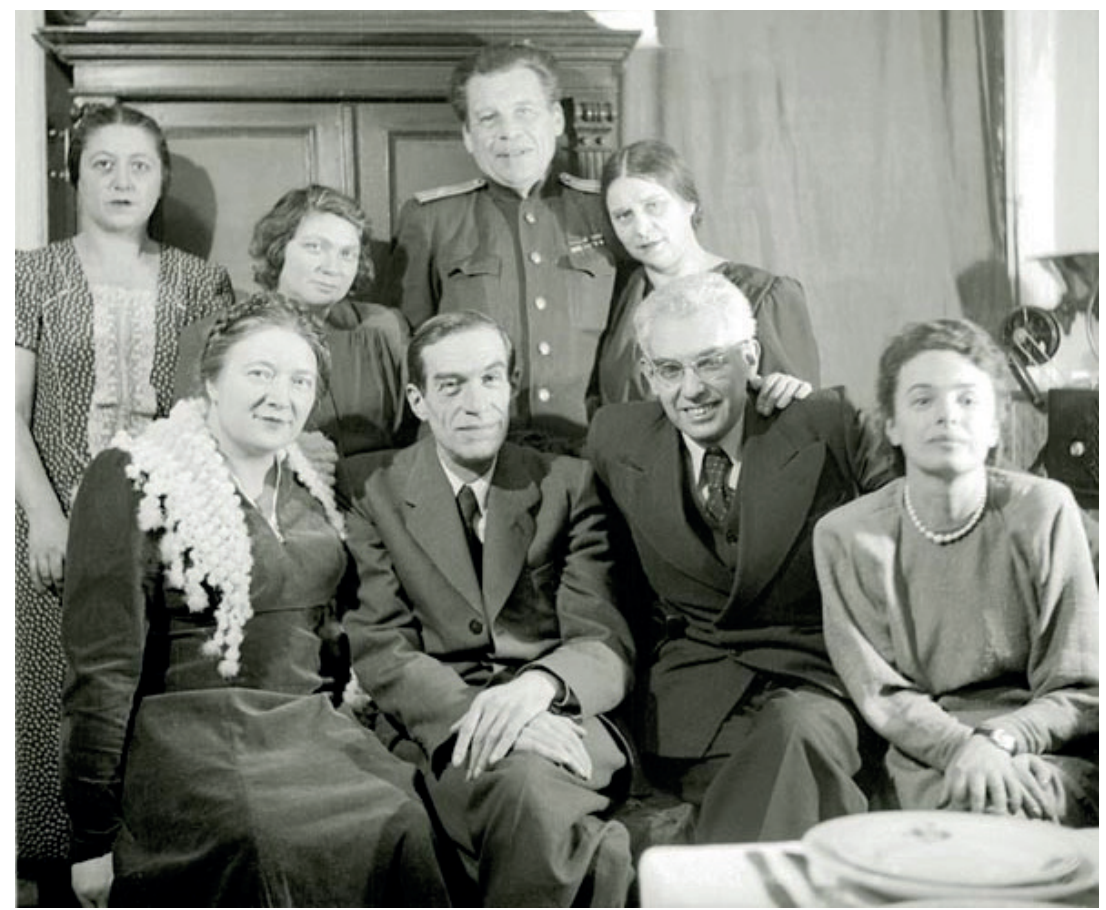

Figure 9. A. N. Leontiev, A.R. Luria (sitting in the center), N. G. Morozova and R. E. Levina (to the left and right of them), T. O. Ginevskaya, L. S. Slavina, L. I. Bozhovich and D. B. Elkonin (standing). Please, note that in the previous photo, Zaporozhets put his hand on Leontiev's shoulder, and in this one - Bozhovich put her hand on Luria's shoulder, i. e. both "elders" are highlighted

\section{The Work Diary}

\section{III.}

Experiment with Zakharov.

1) A pure parietal aphasia ${ }^{20}$ - the impairment of Zusammensehen. ${ }^{21}$

${ }^{20}$ A. R. Luria considered semantic aphasia to be parietal aphasia. The second volume of the planned three-volume book entitled The Study of Aphasia in the Light of the Brain Pathology was called Parietal (Semantic) Aphasia. The first volume of Temporal (Sensory) Aphasia was finished in 1940, and based on that, in 1942, a doctoral dissertation on medicine was defended. In 1940, the second, incomplete and unpublished volume consisted of 219 typewritten pages. It included three different literature reviews - from neurology to linguistics - and showed the role of the simultaneous spatial synthesis (Zusammensehen) and a holistic strategy of perception in the understanding of complex logical and grammatical constructions (Luria A.R., 1940; see also Akhutina \& Agris, 2018).

${ }^{21}$ Zusammensehen (Ger.) - a compound word: zusammen (together) + sehen (see). It means simultaneous vision. 
2) The mechanism of grasping the meaning of a phrase: the patient cannot grasp the implicit sense hidden behind the external phasic ${ }^{22}$ aspect of the phrase; therefore, he:

- either tries to recognize the meaning "in the face," bringing < parts> of the phrase closer to one another and recognizing something familiar in the phrase; understanding by means of recognition,

- or gives a grammatical analysis of the phrase, and due to the preservation of the rules, he gradually gets to the meaning and comes to its evaluation by conclusion (but then he has always got a feeling of uncertainty because there is no grasp).

On the right side: $\underline{N B}$ ! Parietal aphasia.

1) No grasp, zusammen sehen!

2) Hence the attempt to master the concept, semantic structure goes in two ways

| either by the reduction till the recognition (and then the patient acquires a full clarity of | the evaluation)

| or by the increase till the conclusion (and then the patient experiences a feeling of $\mid \underline{\text { uncer- }}$ tainty of his evaluation as there is no inner scheme!)

\section{III.}

Experiment with Usatov.

1) A severe limitation of the field of perception: the patient saw only one object, and the field of vision was regulated not by the spatial principle but by the object field.

2) Memory: the lack of memorization after 150-200 repetitions (with reduced energy activation!).

On the right side:

1): (further experiments with interacting and neighbouring objects are necessary).

2): (further experiments with a mediated memorization are necessary).

$\underline{\text { A talk with A. V. Zaporozhets }}^{23}$

The idea of the rehabilitation role of the compensation!!

19.III.

Wrote a report about the clinic...

20.III.

1) Experiment with Karabanov. To the issue of frontal aphasia.

a) the inability to make an inner field (the experiment with memory - no $<3-4$ letters illegible $>$ ) of memorization;

${ }^{22}$ The opposition of the phasic (external) and inner speech was proposed by L.S. Vygotsky in his Thinking and Speech.

${ }^{23}$ A. V. Zaporozhets (1905-1981) was a known Russian psychologist. He was a student of L. S. Vygotsky and A.R. Luria, a member of the Kharkov group of A. N. Leontiev (see above in the introduction to the second part). 
b) the experiment with $<$ directed? $>$ association $s^{24}-<3$ letters illegible $>$. = naming the same words several times;

c) the experiment with a series $(\ldots+3)$ - repeats the chains audibly!

d) a series of measuring experiments!

2) \{O. P.\} Kaufman's observations of Svetlov: The operation (\{cerebral\} edema) destroys the temporary connections that have been developed by training and leaves a severely impaired functions unchanged!

On the right side:

Parietal lobe: the effect of edema on the destruction of temporary connections.

\section{III.}

Experiment with Karabanov: $:^{25}$ Motor skills

a) inability for narrative motor skills (Apraxie der Handlungsfolge); ${ }^{26}$

b) the impairment of kinetic melodies

\section{III.}

Experiment with Karabanov. $\mathrm{W}^{27}$ of rhythms (the inability for an immediate perception of the rhythms with the following fragmentation). W: easily performs all the trials for the activity if all the $\mathrm{W}$ components are within the field.

\section{III.}

Experiment with Karabanov: the analysis of memory (based on the external mediation: mediated memorization, recognition, etc.).

\section{III.}

Experiment with Karabanov: the analysis of intellectual processes: the inability to grasp the inner meaning of mental structures.

\section{III.}

Experiment with Karabanov: The pictogram and a letter to the wife: the mediation helps.

\section{III.}

Experiment with Karabanov. Memorizing 2 lines of a poem with the interference in learning. The patient is not able for the dynamic generalization of a higher order (i. e., having memorized C,

${ }^{24}$ Possibly, Luria is referring to directed associations, i. e. Semantic Fluency Test.

${ }_{25}$ Pat. Kar. was described in Traumatic Aphasia on pages 79-80 of Russian edition and pages 180-181 of English edition (Luria A. R., 1947/1970).

${ }^{26}$ Apraxie der Handlungsfolge (Ger.) - the apraxia of the action sequence.

${ }^{27} \mathrm{~W}$ - Wahrnehmung [?] (Ger.) - perception. 
he loses E; having memorized $\mathrm{E}$, he loses $\mathrm{C}$, i.e. he does not produce any structure $\mathbb{E}$ [a curly bracket above $\mathrm{E}]$.

No records from 26.III till 16.IV.

\section{IV.}

1) Vostrikov - Injury to the left frontotemporal area. Premotor syndrome $\rightarrow$ premotor speech impairments, functional layers on premotor disorders.

2) Belonogov - concussion syndrome, asthenia, fatigue.

Counting disability by type of link omission.

3) Melnichenko - the 7th (Brodmann) area syndrome ${ }^{28}$ (the deficit of the differentiation of contralateral movements, with intact kinetic melodies and strength).

4) Evstakhiev - premotor impairment, with symptoms of a healthy (ipsilateral) hand.

\section{IV.}

Experiment with Polyakov: The right premotor area syndrome (1. Impulsivity with the deficit of <splitting > self-consciousness and 2. motor skills: the inability for perceiving and repeating rhythms).

\section{On the right side: $\mathbf{N B}$ !}

\section{IV.}

1) The basic idea: the premorbid level has \{a value $\}$ in that sense that after injury, the ability to keep former traces and to form new connections suffers in different ways. Thus, in a person with a low premorbid condition, the injury may cause the "disturbance" of those principles which are intact in another individual. This is not because of the severity of the injury but due to the fact that in patients (A), that function runs in the order of the formation of new connections and in the order of the reproduction of previous ones in patients (B).

2) A number of patients with negative symptoms: soft tissue injury may cause a transient contusion of this system... but a very rapid and full restitution (cf. Gabdullin, Agabekov, etc. - the rehabilitation of the left temporal region).

3) The injury can lead not only to the loss but also the weakening of the function - by type of Sehschwäche (cf. patient Kalabekov) or Hörschwäche ${ }^{29}$ (cf. patients Gabdullin, Kopalo, etc.).

\section{IV.}

Experiment with Dgantuev — universal aspontaneity (without any frontal semiology).

\section{IV.}

The impairment of sense comprehension in frontal patients!

On the right side: SENSE AND MEANING (frontal and posterior lesions)

\footnotetext{
28 Upper sections of the parietal lobe.

29 Sehschwäche, Hörschwäche (Ger.) - poor vision, poor hearing.
} 


\section{A trip to Moscow}

\section{VI.42.}

Experiment with Moiseev; a conversation with \{O. P.\} Kaufman.

The interzonal interaction. Each zone has its specific function but simultaneously - contributes its component to the organization of work of other zones; in parietal lesions, the temporal region begins functioning in a different way (through the insula?); this is expressed in the inability to grasp the simultaneous schemes of acoustic processes - and particularly - the inability to grasp the sound structure of the word, the inability to acquire a complex structure of the rhythm (cf. || || || +; || | || | - this rhythm - does not go at all!).

Hence - parietal syndrome: the impairment of simultaneous schematization in optics (the spatial arrangement), in grammar, in counting; — the same in acoustics!!

On the right side: $\mathbf{N B}\{$ on one line with $\underline{\text { The interzonal interaction }\}}$

\section{VI.42.}

1) Observation patient Snekov: in parietal lesions, any task hidden behind the question is understood (the patient knows what he needs to answer) but the structure of the question is not grasped.

\section{On the right side: NB: Sense and meaning.}

In frontal lesions, concussions and general dementias - a patient does not grasp the sense of the question, i. e. the assigned task remains unclear - and he has the tendency not to answer the question but to repeat the question approaching echolalia!

On the right side: Cf. patient Davydov!

2) Patient Petrov (\{E.\} Bein) - a pure temporal syndrome! Trained to acquire sounds through the letter.

3) Patients Barsuk and especially Mitskevich — residual, stable impairment of active frontal systems. Frontal Abstimmung ${ }^{30}$ of speech function - expressed in the deautomatization of speech, its aspontaneity and the impairment of the THOUGHT $\rightarrow$ SPEECH system with a sufficient intactness of the $\mathrm{W} \rightarrow \mathrm{SPEECH}$ system; hence the intactness of naming the objects and an acute amnesia in the spontaneous speech.

On the right side: Frontal aphasia!

Cf. Mitskevich! cf. Shingarev! cf. Karabanov! cf. Sychev!

4) Zozulya - the 37 th area syndrome (occipital-temporal syndrome) - the impairment of the recollection of words, no parietal impairments.

\footnotetext{
${ }^{30}$ Abstimmung (Ger.) — adjustment.
} 
On the right side: Occipital-temporal syndrome?

5) Kasheev - The T3 syndrome: ${ }^{31}$ the impairment of acoustic and speech memory, with an intact phoneme differentiation.

On the right side: The T3 syndrome

\section{VI.}

1) Buyskikh - a case with negative aphasic symptoms in the latent left-hander. The hypothesis of a LATENT ambivalence of the hemispheres and a recessive heredity of the hemispheric dominance: the patient with heredity (his genealogy is in Figure 10). \{This patient is described in Traumatic Aphasia, case 2 (Luria A. R., 1947, p. 37-38 / 1970, p. 63-64)\}

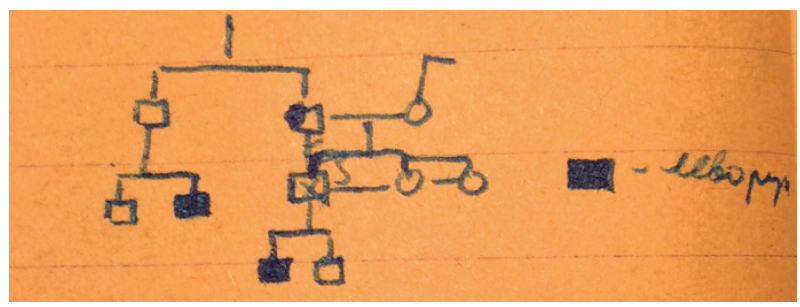

Figure 10. Genealogy of patient Buysk.

2) Premotor syndrome: Vostrikov! Diuzhev!

3) Davydov: a severe impairment of the left hemisphere! Primitiveness of the psyche - against the background of a relative intactness of the sound aspect of speech.

4) Experiment with Nikanorov:

a) the stages of phonemic difficulties in writing (delays - transposition of sounds - substitutions).

b) Assertion: in local concussions (without any damage to the integrity of the brain) - not the disintegration syndrome but the SYNDROME OF LOCAL ASTHENIZATION!

- different dynamics of the structure;

- a different course;

- a different prognosis.

On the right side: Cf. Sultanov! Cf. Blinnikov!

Theme: CLINICAL SYNDROMES of traumatic aphasia

(forms of destruction - the form of asthenias)

\section{VII}

1) Experiment with premotor syndrome $\Pi / \triangle \Pi / \wedge^{32}$

I. A group of premotor patients produce clear and persistent symptoms

31 T3 syndrome - syndrome of damage to the lower temporal gyrus.

32 П/Л \ - The Graphomotor Sequences Test. 
II. A group of marginal premotor patients - unstable and easily treatable symptoms III. A group of premotor, frontotemporal patients - may not produce symptoms

IV. A group of the right premotor patients - ??

2) Kosrochenko - the disintegration of the structure of complex actions in frontal abscess.

\section{VII}

Experiment with Kosrochenko.

1) Frontal lesions - the disturbance of motivation, field factors and clichés instead of motives Memory - instead of recollections $\rightarrow$ associations, "floating up";

W. $\{$ perception\} - within impressions!

Understanding - only of an external situation but not the motives.

2) Rehabilitation - (compensation); ways (a) through dividing a complex instruction into parts, (b) through changing the context!!

On the right side:

1) The illustration to the Frontal chapter (the traumatic material).

2) With Bl. V. \{Zeigarnik\} - meaning / sense!! structure mental < processes $>$ in frontal lesions! For 2) NB. To the theory of the compensation (overcoming) of frontal lesions!

\section{VII.}

1) An experiment with Kuybar. Pseudo-semantic syndrome in the left temporal lobe lesion.

The impairment of the understanding of grammatical structures - but with the possibility of the compensation! (due to the inability to retain the series).

The impairment of oral counting - written counting is intact.

2) Experiment with Volkov: T3 syndrome

The intactness of the $\mathrm{W}$. \{perception\} of phonemes, the intactness of the understanding of words (no alienation), the intactness of the sound analysis - the disturbed series!!

On the right side:

The pseudo-semantic (temporal) impairment.

\section{T3!!}

\section{VII.}

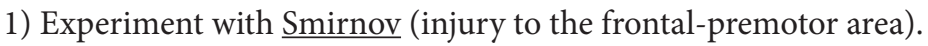

a) Shrapnel leucotomy! ${ }^{13}$ The separation of the whole frontal system!! Hence the disturbance of sense - with the intact meaning.

b) Against the background of the general aspontaneity - mild impairments of premotor speech.

NB: the reverse development of speech was delayed!!

${ }^{33}$ Leucotomy (lobotomy) - the dissection of the white matter of the brain. 
On the right side: Military expert Egas Moniz!! ${ }^{34}$

25.VII.

Experiment with Brozgalov: The T2 syndrome (intermediate between T1 and T3!! $)^{35}$

On the right side: $\mathrm{T} 2$

\section{VII.}

New aphasic patients (the general examination).

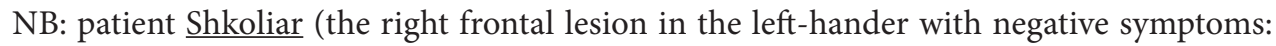
a latent right-handed person!!).

On the right side: NB: Fig. 11. A genotypic causation of the dominance (a latent recessive right-hander!!)

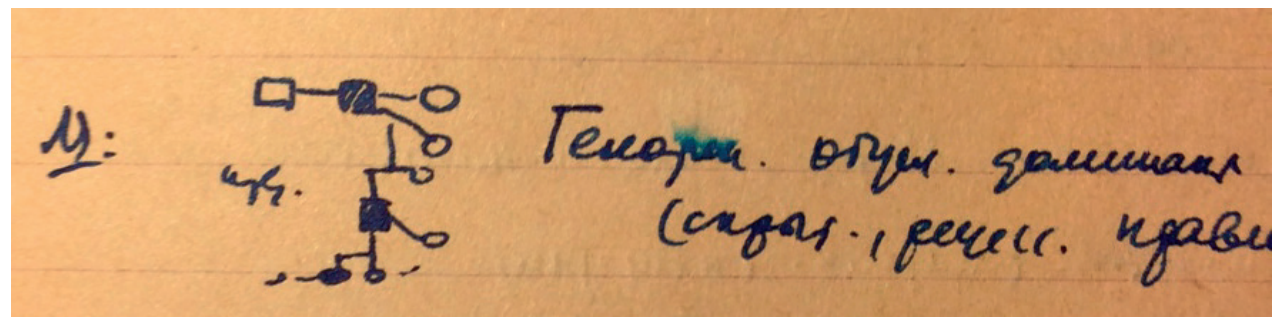

Figure 11. Pat. Shk.

\section{VII.}

Prosvetov - a severe premotor symptom complex.

A new sensitized trial (finger sequencing).

\section{A departure for Kazan}

\section{VIII}

Experiment with Ivanov.

Awkwardness - parietal (extra-spatial)

$$
\begin{aligned}
& \text { - thalamic (postural) } \\
& \text { - premotor (dynamic) }
\end{aligned}
$$

${ }^{34}$ Egas Monitz was a Portuguese neurologist and the developer of cerebral angiography. He was regarded as one of the founders of modern psychosurgery, having developed the surgical procedure of leucotomy known better today as lobotomy. Owing to that fact, he became the first Portuguese national to receive a Nobel Prize in 1949 (shared with Walter Rudolf Hess).

\footnotetext{
${ }^{35}$ Syndromes T1, T2 and T3 are syndromes of lesions of the superior, middle and inferior temporal gyri.
} 


\section{VIII}

Kulagin (\{with O. P.\} Kaufman). 1) Optical agraphia! 2) the cerebral sinus syndrome

\section{VIII.}

1) Kertbat - a reverse development of syndrome T2-3 brings reveals the lesion of successive processes, the impairment of acoustic mnesis and the disturbance of word stress. ${ }^{36}$

2) Odinets - T3 (fully rehabilitated).

On the right side: Dynamic reversals of the injuries to T3

\section{VIII}

1) Kharin - mild symptoms of the frontal lobe.

Pimenov - a negative case: injury to the soft tissues of the frontal lobe without any symptoms.

2) Kulichkov - motor agrammatism with telegraphic style.

3) Barsenev - (Perelman's ${ }^{37}$ patient). A neurodynamic genesis of stuttering in concussion patients. (The conflict of increased inertia of excitation - with a tendency to active speech.)

On the right side:

$\mathrm{NB}$

\begin{tabular}{|c|}
\hline Neuro-dynamic dysphasia! \\
in a concussion patient \\
\{with mixed dominance $\}$ \\
\hline
\end{tabular}

\section{VIII}

1) Guriakov. The delineation of aphasia from the frontal disturbances (frontotemporal aphasia).

2) Furman, Antonov. Frontal and premotor impairments.

\section{VIII}

1) Bursiagin. Temporal aphasia. A disturbed repetition and naming of words.

2) Kondratenko. Frontal aphasia (the spontaneous speech impairment).

\section{IX.}

Katkov -injury to the left frontotemporal area with the following rapidly-passed aphasia (left-handedness in the family, see Figure 12). \{See Traumatic Aphasia, case 6 (Luria A. R., 1947, p. 39-40 / 1970, p. 67)\}

${ }^{36}$ Word stress is a relative emphasis or accent given to a certain syllable in the word.

${ }^{37}$ L. B. Perelman is a staff member of the hospital, a neuropathologist and the author of the book Reactive Post-Concussion Deaf-Muteness, its Identification and Treatment (1943). 
On the right side:

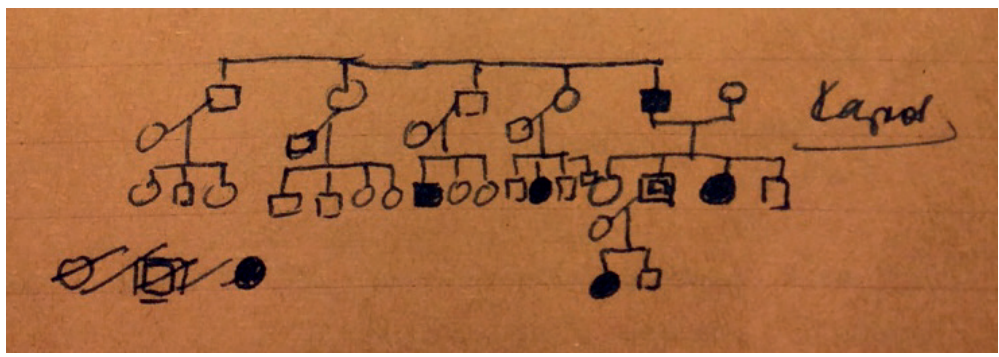

Figure 12. Genealogy of patient Katk.

\section{IX.}

Experiment with $\underline{\text { Karabanov (Bassin). }}{ }^{38}$ The inability (illegible) the genuine melody design.

\section{IX}

1) Experiment with Karabanov - the impairment of fluency in W. (perception) and thinking (a disturbed internal field).

2) Observations over Makr (illegible). The disturbance of voluntary processes.

The essence of hysteria: Usually, involuntary processes become voluntary but the voluntary flow of processes is disrupted.

The levels of voluntariness and levels of disintegration.

\section{IX}

Experiments with aphasia.

Motor-aphasic thought impairment (with O. P. Kaufman).

\section{IX}

1) Kondratenko. Rhythms. Automation impairment (premotor syndrome).

2) Prosvetov. Rhythms. Frontal syndrome. The tension of the motor set in delayed actions.

3) Surovtsev, Sarovets. Rhythms. Disturbed rhythms of the afferent type.

\section{X. 42.}

\begin{tabular}{l|l} 
Prokhorov & Sense and meaning \\
Moiseev & in frontal lesions
\end{tabular}

${ }^{38}$ F. V. Bassin (1905-1992) was a staff member of the hospital, a psychologist. He was a member of L.S. Vygotsky's circle and became a well-known psychologist and neurophysiologist, an expert in the psychology of the unconscious. He was one of the initiators and organizers of the Tbilisi Symposium on the unconscious. 


\section{X.42.}

1) Experiment with Sehschwäche ${ }^{39}$ in the occipital injury (Zakharchenko): it is "removed" by glasses, i. e. "an unclear vision" presbyopia ${ }^{40}$ ceases to be compensated.

2) Experiment with Prokhorov: a frontal patient: understanding the sense - counting (division) - rhythms.

3) Experiment with Kubyshkin: a compensated impairment of functions in the impaired frontal lobe in the ambidextrous person (Figure 13, at the top). NB: ambidextria! (on the right side).

9.X.42. Nadezhdin: a left-hander with the injury to the right premotor zone and the corresponding dominant hemi-syndrome (Figure 13, at the bottom) (on the right side).

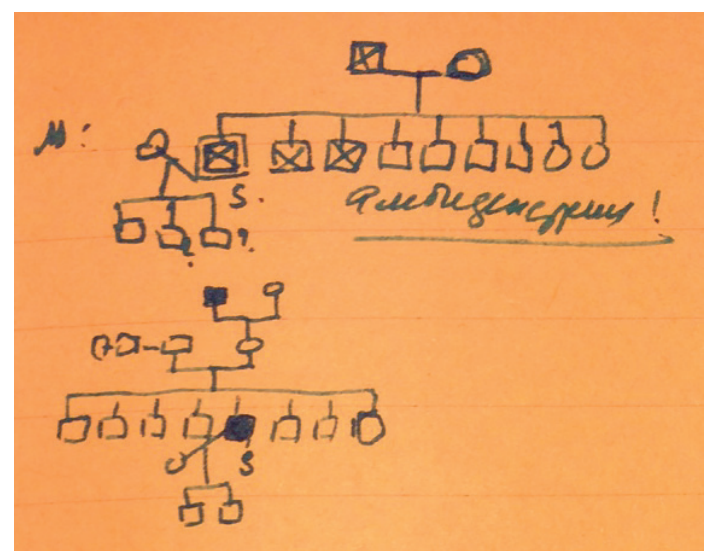

Figure 13. Genealogy of patients Kub. (at the top) and Nad. (at the bottom)

\section{0-16.X.42.}

With O.P. Kaufman. The development of issues on motor aphasia.

1) The classification of motor aphasias (phasic - denervated - dynamic)

2) Different ratios of speech/thought in them.

\section{X.42.}

1) Komarov. A severe motor aphasia without any semantic disorders in the patient with the injury to the left hemisphere - with a hidden gene of left-handedness gives very minor semantic and $<$ motor $>$ disorders and severe impairments of motor speech (Figure 14).

${ }^{39}$ Sehschwäche (Ger.) - poor vision.

${ }^{40}$ Presbyopia (aged sight) is a refractive error of the eye in which a person cannot focus on the fine print or small objects at the close distance. 
On the right side:

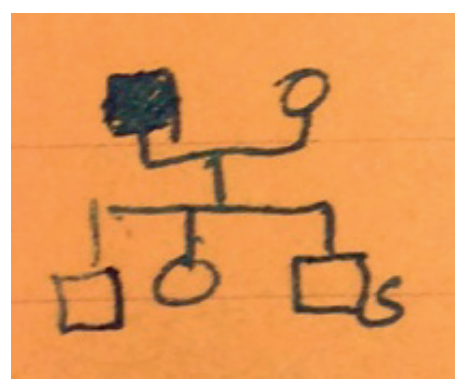

Figure 14. Genealogy of patient Kom.

2) The analysis of motor aphasias: Classification by

\begin{tabular}{lccc} 
& phasic & denervated & dynamic \\
\cline { 2 - 4 } $\begin{array}{l}\text { "length" } \\
\text { and }\end{array}$ "depth" & speech & speech & speech \\
\cline { 2 - 4 } & writing & - & - \\
\cline { 2 - 4 } & syllog. exp. ${ }^{41}$ & - & - \\
\hline
\end{tabular}

\section{X.}

Saborov: agrammatism. A disturbed scheme of the phrase.

\section{X.}

Gazdiuk: Subcortical concussion syndrome (pseudo-parkinsonism; with a frontal-subcortical defect).

\section{X.}

1) Baranishin — frontal syndrome (b). 2) Saborov — the impairment of the flow of intellectual processes in frontal aphasia.

28.X.

Saborov - the inability to retain the sequence.

\section{X.}

1) Saborov - Compensation in series sequences

$=\mid-$ with reflection.

| = - easy!!

\{The series is surrounded by a triangle showing the decreasing structure of the series. Perhaps, it was a trial for constructing a serial sequence with sticks\}.

${ }^{41}$ Syllog. exp. - seemingly, Luria implied tests for understanding syllogisms. He used them to study thinking in frontal impairments or semantic aphasia. 
2) The right frontal lobe - Leidest, Peschanov - Rhythms: the evaluation of " as "' $\{$ i. e. the evaluation of the rhythm "by 2" as "by 3 " $\}$ - there is an impairment of the sensory denervation ( 2 times are loud - one time is quiet).

On the right side: NB!! The disturbance of rhythms assessment = the phenomenon of the impairment of sensory denervation!!

\section{XI.}

More cases of a latent left-handedness! (Katkov!)

\section{XI.}

1) Saborov - an experiment with memorizing a poem — the disintegration of the structure of the poetic rhythm.

2) Togadev: slight remnants of premotor aphasia ("house-table-cat" $\{$ It is Luria's test for verbal memory\})

On the right side: $\mathrm{NB}$

\section{XI.}

1) Saborov - the frontal disintegration of perception

2) $\underline{\text { Saveliev }}$ - a disturbance of $<$ illegible $>$ actions

\section{XI.}

1) Khristov - temporal aphasia.

A new sensitized method for studying the alienation of words (excluding the active speech).

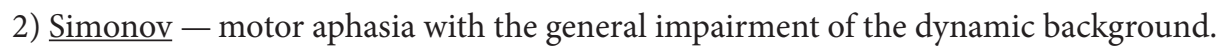

\section{0-11.XI.}

Experiments with rhythms.

1) The mediation by the space (optical memory) and speech.

\section{XI.}

Experiments with rhythms: the mediation by speech images "mAmmy — banAna" in temporal patients gives no results (Bursiagin, Khristov) \{this refers to the use of stress in words: in the word "mAmmy" stress is on the first syllable, in the word "banAna" - on the second syllable\}.

\section{XI.}

1) Saveliev | the impairment of simple rhythms and their mediation

2) Shegalov | "dAddy - informAtion" \{in the word "daddy" ['dædr], the stress is on the first syllable, in the word "information" [Info'meifn] — on the third syllable\}.

\section{(The end of the records in the year of 1942)}

\section{To be continued...}




\section{Acknowledgements}

The authors express deep gratitude to all colleagues who shared their memories or materials about the psychologists of the A. R. Luria's circle. Special thanks to V.V. Nikolaeva, E. E. Sokolova, M. A. Stepanova, N. V. Zvereva and O. D. Larina.

\section{References}

Akhutina, T. V. (2012). Comments on two documents from the archive of A. R. Luria. Issues of Psycho$\log y, 4,71-85$. [In Russian]

Akhutina, T. V., \& Agris, A. R. (2018). History of studying semantic aphasia mechanisms (Based on materials from Lurian archive). In J. M. Glozman, O. S. Vindeker, I. A. Ershova, \& M. E. Permiakova (Eds.), The Fifth International Luria Memorial Congress "Lurian approach in international psychological science", KnE Life Sciences, 30-41. https://doi.org/ 10.18502/kls.v4i8.3260

Bein, E. S. (1949). The psychological analysis of sensory aphasia (Doctoral dissertation). Moscow: Academy of Medical Sciences of the U.S.S.R. [In Russian]

Bein, E. S., \& Kaufman, O. P. (1952). The rehabilitation of speech processes in traumatic aphasia (Album). Moscow: AMS USSR. [In Russian]

Birenbaum, G. (1930). Forgetting intention. Psychologische Vorschung, 13(2-3), 218-285. [In German]

Birenbaum, G. V., \& Zeigarnik, B. V. (1935). To the dynamic analysis of thinking disorders. The Soviet Neuropathology, Psychiatry and Hygiene, 4(6), 75-98. [In Russian]

Bozhovich, L. I. (1988). About the cultural-historical concept of L. S. Vygotsky and its significance for the modern research of the psychology personality. Issues of Psychology, 5, 107-114. [In Russian]

Chronicle of 1942 (2004, May). Moscow University newspaper, 19(4080). Retrieved from http://www.getmedia.msu.ru/newspaper/newspaper/4080/all/250.htm [In Russian]

Cole, M., Levitin, K., \& Luria, A. R. (2006). The autobiography of Alexander Luria: A dialogue with the making of mind. Mahwah, NJ: L. Erlbaum Associates.

Galperin, P. Ya. (1934). The psychological sector. In: M. A. Goldenberg (Ed.), The All-Ukrainian Psychoneurological Academy: The Collection of Materials. Scientific activity (Vol. 1, pp. 33-36). Kharkiv: UPNA.

Galperin, P. Ya., \& Ginevskaya, T. O. (1947). The dependence of volume of movement from the psychological nature of the problem. Scientific notes of the Moscow State University, 111, 75-79.

Ginevskaya, T. O. (2005). Memories of A. V. Zaporozhets. In: L. A. Paramonova (Ed.), A. V. Zaporozhets A man and a thinker. The memories of colleagues, students and friends. Proceedings of the International anniversary scientific conference on the 100th anniversary of the birth of A. V. Zaporozhets (pp. 6-46). Moscow: Karapuz-Didaktika. [In Russian]

Gutkina, N. I. (2008). Lidiya Ilinichna Bozhovich: The biographical essay. Cultural-Historical Psychology, 4(4), 12-17. [In Russian]

Homskaya, E. D. (2001). Alexander Romanovich Luria. A scientific biography. New York, NY: Kluver.

Kaufman, O. P. (1947). Speech rehabilitation in motor aphasia. The Scientific Notes of the MSU. Psycho$\log y, 111(2), 126-130$. [In Russian] 
Kaufman, O. P. (1949). About the optical agraphia. In: N. I. Grashchenkov (Ed.), Neuropathology in the wartime. Proceedings of the Institute of Neurology of the USSR Academy of Medical Sciences (pp. 189-199). Moscow: Academy of Medical Sciences Press. [In Russian]

Leontiev, A. A., Leontiev, D. A., \& Sokolova, E. E. (2005). Alexei Nikolaevich Leontiev. Activity, consciousness, personality. Moscow: Smysl. [In Russian]

Leontiev, A. N. (1965). Problems of the development of the mind (2nd ed.). Moscow: Smysl. [In Russian] (Original work published 1959)

Leontiev, A. N., \& Zaporozhets, A. V. (1945). The rehabilitation of movement: The study of the hand function rehabilitation after injury. Moscow: Sovetskaya Nauka. [In Russian] (English translation: Leontiev, A. N., \& Zaporozhets, A. V. (1960). Rehabilitation of hand function (B. Haigh, Trans.). London: Pergamon Press)

Luria, A. R. (1940). The study of aphasia in the light of brain pathology. Part 1: Temporal (sensory) aphasia. Part 2: Parietal (semantic) aphasia. Unpublished manuscript. The E. G. Radkovskaya archive, Moscow. [In Russian]

Luria, A. R. (1970). Traumatic aphasia. The Hague: Mouton. (Original work published 1947)

Luria, A. R. (1972). The man with a shattered world. New York: Basic Books. (Original work: Luria, A.R. (1971). The lost and returned world. Moscow: Moscow University Press)

Luria, A. R. (1982). Steps of the passed way: Scientific autobiography. Moscow: Moscow University Press. [In Russian]

Luria, A. R. (2003). The ways of the early development of the Soviet Psychology. In: A. R. Luria (Ed.), Psychological heritage (pp. 259-274). Moscow: Smysl. [In Russian]

Luria E. A. (1994). My father A. R. Luria. Moscow: Gnozis.

Nikolaeva, V. V., \& Polyakov, Yu. F. (2016). Bluma Vulfovna Zeigarnik. The Zeigarnik phenomenon (1900-1988). In V.V. Rubtsov, T. D. Martsinkovskaya, \& M. G. Yaroshevsky (Eds.), Outstanding psychologists of Moscow (pp. 301-308). Moscow: MGPPU. [In Russian]

Perelman, L. B. (1943). Reactive Post-Concussion Deaf-Mutism, its recognition and treatment. Moscow, Chelyabinsk: Medgiz. [In Russian]

Rubinstein, S. Ya. (1949). The examination and the rehabilitation of working ability after military brain injuries. In: N. I. Grashchenkov (Ed.), Neuropathology in the wartime (pp. 294-308). Moscow: Academy of Medical Sciences the USSR. [In Russian]

Rubinstein, S. Ya. (1970). Experimental methods of patopsychology. Moscow: Meditsina. [In Russian] Shokhor-Trotskaya, M. K. (2001). The strategy and tactics of speech rehabilitation. Moscow: Eksmo-Press, V. Sekachev. [In Russian]

Sokolova, E. E. (1995). Letters of psychologists of the Kharkiv group to A. N. Leontiev during the war. Psychological Journal, 16(5), 4-11. [In Russian]

Stepanova, M. A. (2017). Psychologist, physician, philosopher: milestones of the scientific biography of P. Ya. Galperin. National Psychological Journal, 3(27), 21-32. [In Russian]

Vygodskaya, G. L., \& Lifanova, T. M. (1996). Lev Semyonovich Vygotsky. Life. Activity. Touches to the portrait. Moscow: Smysl. [In Russian]

Vygotsky, L. S. (1993). The Collected Works: Vol. 2. The Fundamentals of Defectology (J.E. Knox \& B. C. Stevens, Trans.). New York: Plenum Press. (Russian edition: Vygotsky, L. S. (1983). The Collected Works: Vol. 5. The Fundamentals of Defectology. Moscow: Pedagogica) 
Vygotsky, L. S. (1997). The problem of consciousness. In R. W. Rieber \& J. Wollock (Eds.), The collected works of L.S. Vygotsky: Vol. 3. Problems of the theory and history of psychology (pp. 129-138). London: Plenum Press. (Russian edition: Vygotsky, L. S. (1982). The problem of consciousness. In A. R. Luria, \& M. G. Yaroshevsky (Eds.), The Collected Works: Vol. 1. Problems of the theory and history of psychology (pp. 156-167). Moscow: Pedagogika)

Vygotsky, L. S. (2004). The letters to students and colleagues. The Moscow University Bulletin. Series 14. Psychology, 3, 3-40. [In Russian]

Wilson, B. A., Baddeley, A., Evans, J. D., \& Shiel, A. (1994). Errorless learning in the rehabilitation of memory impaired people. Neuropsychological Rehabilitation, 4(3), 307-326. https://doi.org/10.1080/09602019408401463

Yasnitsky, A. (2008). An essay on the history of the Kharkiv school of psychology: The period of 1931-1936. Cultural-Historical Psychology, 4(3), 92-102. [In Russian]

Zaporozhets, A. V. (1982). A. R. Luria's role in the development of the Soviet Psychology. In:

E. D. Homskaya (Ed.), Luria A. R. and the modern psychology (pp. 10-21). Moscow: Moscow University Press. [In Russian]

Zaporozhets Alexander Vladimirovich (2020, May 29). Wikipedia, the free encyclopedia. Retrieved from https://ru.wikipedia.org/?oldid=107357231 [In Russian]

Zaporozhets, A. V., \& Rubinstein, S. Ya. (1942). Methods of restorative occupational therapy for injuries to upper limbs. Moscow: Medgiz. [In Russian]

Zaporozhets, A. V., \& Rubinstein, S. Ya. (1947). Psychophysiological issues of the organization of restorative occupational therapy. The Scientific Notes of the MSU. Psychology, 111, 150-156. [In Russian]

Zavershneva, E., \& Van der Veer, R. (Eds.). (2017). L. S. Vygotsky's notebooks. Selected. Moscow: "Kanon+" ROII "Rehabilitation”. [In Russian]

Zeigarnik, A. V. (2001). Bluma Vulfovna Zeigarnik (An attempt to reproduce the life path). Counselling Psychology and Psychotherapy, 9(4), 182-193. [In Russian]

Zeigarnik, B. (1927). About keeping finished and unfinished actions. Psychologische Forschung, 9, 1-85. [In German]

Zeigarnik, B. V. (1934). To the problem of understanding the figurative meaning of words or sentences in pathological changes of thinking. In The Innovation in the Study of Apraxia, Agnosia, and Aphasia (pp. 132-146). Moscow, Leningrad: Medgiz. [In Russian]

Zeigarnik, B. V. (1943a). To the question of local and general brain factors in frontal brain disorders. Journal of Neuropathology and Psychiatry Named after S. S. Korsakov, 12(6), 40-44. [In Russian]

Zeigarnik, B. V. (1943b). The psychological analysis of post-concussion impairments of hearing and speech. In: L. B. Perelman (Auth., Ed.), Reactive Post-Concussion Deaf-Mutism, its recognition and treatment (pp. 41-55). Moscow, Chelyabinsk: Medgiz. [In Russian]

Zeigarnik, B. V. (1947). Experimental and psychological data in injuries of the frontal brain lobes. Collected Works of the Central Institute of Psychiatry (Vol. 3). Moscow: Medicine. [In Russian]

Zeigarnik, B. V. (1976). Pathopsychology. Moscow: Moscow University Perss. [In Russian]

Zeigarnik, B. V., \& Birenbaum, G. V. (1935). To the problem of the semantic perception. The Soviet Neuropathology, Psychiatry and Hygiene, 4(6), 57-74. [In Russian]

Zeigarnik, B. V., \& Rubinstein, S. Ya. (1982). The contribution of Luria to pathopsychology during the Great Patriotic War (the Second World War). In: E. D. Homskaya (Ed.), A. R. Luria and contemporary psychology (pp. 68-71). Moscow: Moscow University Press. [In Russian] 
Zinchenko, V. P. (2011). My teachers and distinguished interlocutors. In: T. G. Shchedrina (Ed.), Thinking style: The problem of the historical unity of the scientific knowledge. On the 80th anniversary of Vladimira Petrovicha Zinchenko (pp. 231-584). Moscow: ROSSPEN. [In Russian]

Zvereva, N. V. (2012). Susanna Yakovlevna Rubinstein (1911-1990): The service to the cause (On the 100th anniversary of her birth). Medical Psychology in Russia: Electronic Scientific Journal, 1. Retrieved from www.medpsy.ru/mprj/archiv_global/2012_1_12/nomer/nomer02.php. [In Russian]

\section{Appendix \\ Приложение}

Это приложение мы решили дать, поскольку текст «Дневника работы» представляет собой личные записи. Перевод такого текста на иностранный язык не исключает возможность субъективной интерпретации написанного. Чтобы избежать этого риска и позволить читателям самим ознакомиться с первоисточником, в приложении мы публикуем записи на языке оригинала. В тексте «Дневника» содержатся сокращения. Их объяснение дано в квадратных скобках. Неразборчивые слова заключены в угловые скобки, а вставленные слова - в фигурные скобки. Нумерация рисунков приводится в соответствии с английским вариантом.

\section{Дневник работы}

\section{III.}

Опыт с Захаровым.

1) Чистая теменная афазия ${ }^{1}$ - нарушение Zusammensehen ${ }^{2}$ [симультанного видения].

2) Механизм схватывания смысла фразы: больной не может схватить скрытый за внешней фазической ${ }^{3}$ стороной фразы смысл; поэтому он

- или старается узнать смысл в лицо, сближая <части> фразы друг с другом, узнавая знакомое в фразе; понимание методом узнавания,

- или дает грамматический анализ фразы и так как у него сохранены правила - он постепенно добирается до смысла и приходит к его оценке методом умозаключения (но тогда у него все время остается чувство неясности, ибо нет схватывания).

1 Теменной афазией А. Р. Лурия называл семантическую афазию. Второй том из задуманного трехтомника под названием «Учение об афазии в свете мозговой патологии» назывался «Теменная (семантическая) афазия». Первый том «Височная (сенсорная) афазия» был закончен в 1940 г., и в 1942 г. на его основе была защищена докторская диссертация по медицине. Второй, незаконченный и неизданный том в 1940 г. включал 219 машинописных страниц. Он содержал три разных обзора литературы - от неврологии до лингвистики - и показывал, какова роль симультанного пространственного синтеза (Zusammensehen) и целостной стратегии восприятия в обеспечении понимания сложных логико-грамматических конструкций (Luria A. R., 1940; см. также: Akhutina \& Agris, 2018).

${ }^{2}$ Zusammensehen (нем.) - сложное слово, состоящее из двух частей: Zusammen (вместе) и sehen (видеть).

${ }^{3}$ Противопоставление фазической (внешней) и внутренней речи было предложено Л.С. Выготским в «Мышлении и речи». 


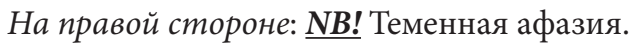

1) Нет схватывания, zusammen sehen!

2) отсюда попытка овладеть понятием, смысловой структурой идет двумя путями

| или снижением до узнавания (и тогда_больной приобретает полную | ясность оценки)

| или поднятием до умозаключения (и тогда у больного остается ощущение | неясности своей оценки, так как внутренней схемы нет!).

\section{III.}

\section{Опыт с Усатовым.}

1) Грубое ограничение поля восприятия: больной видел лишь один предмет, и поле зрения регулируется не пространственным, а предметным принципом.

2) Память: отсутствие запоминания после 150-200 повторений (при энергетической сниженности!).

\section{На правой стороне:}

Напротив 1): (нужны дальнейшие эксперименты на взаимодействующие и сопутствующие объекты).

Напротив 2): (нужны дальнейшие эксперименты с опосредованным запоминанием).

Беседа с А. В. Запорожцем ${ }^{4}$

Идея восстанавливающей роли компенсации!!

\section{III.}

Писал отчет о клинике.

\section{III.}

1) Опыт с Карабановым ${ }^{5}$. К лобной афазии.

а) невозможность создать внутреннее поле (опыт с памятью - нет <3-4 буквы нрзб>) запоминания;

b) опыт с огр<аниченными? $>$ ассоциациями ${ }^{6}-<3$ буквы нрзб >. = перечисление по несколько раз тех же слов;

с) опыт с числовым рядом $(\ldots+3)-$ повторяет вслух звенья!

d) серия измерительных опытов!

2) Наблюдения \{О. П.\} Кауфман над Светловым: Операция (отек) разрушает временные связи, возникшие в результате обучения, и оставляет без изменения грубо нарушенное!

На правой стороне: Темя: влияние отека на разрушение временных связей.

${ }^{4}$ А. В. Запорожец (1905-1981) - известный российский психолог (подробнее см. во введении к этой части).

${ }^{5}$ Больной Кар. описан в «Травматической афазии» (Luria A. R., 1947, p. 79-80 / 1970, 180-181).

${ }^{6}$ Возможно, Лурия имеет в виду направленные ассоциации. 


\section{III.}

Опыт с Карабановым: Моторика

a) невозможность повествовательной моторики (Apraxie der Handlungsfolge) ${ }^{7}$;

b) нарушение возможности кинетических мелодий

\section{III.}

Опыт с Карабановым. $\mathrm{W}^{8}$ ритмов (невозможность сразу воспринять ритмы с расчленением на фрагменты). W: легко делает все пробы на активность, если все компоненты W есть в поле.

\section{III.}

Опыт с Карабановым: анализ памяти (опора на внешнее опосредование: опосредованное запоминание, узнавание и т. д.).

\section{III.}

Опыт с Карабановым: анализ интеллектуальных процессов: невозможность схватить внутренний смысл интеллектуальных структур.

\section{III.}

Опыт с Карабановым: Пиктограмма и письмо жене: опосредование помогает.

\section{III.}

Опыт с Карабановым. Заучивание 2 строчек стихотворения с интерференцией заучивания. У больного не получается динамическое обобщение высшего порядка (т.е. он, заучив С, теряет Е, заучив Е, теряет С, т. е. не вырабатывает структуры С [сверху фигурная скобка].

\section{26.III no 16.IV нет записей.}

\section{IV.}

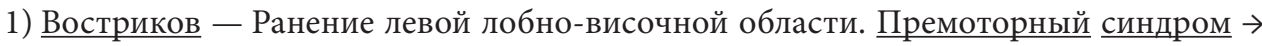
премоторные нарушения речи, функциональные напластования на премоторные нарушения.

2) Белоногов — коммоционный синдром, астения, истощаемость. Нарушения счета по типу упускания звеньев.

3) Мельниченко - синдром 7-го поля9 (дефект дифференциации контрлатеральных движений при сохранении кинетических мелодий и силы).

4) Евстахиев - премоторное нарушение с симптомами здоровой (ипсилатеральной) руки.

${ }^{7}$ Apraxie der Handlungsfolge (нем.) - апраксия последовательности действий. Описана K. Kleist.

${ }^{8}$ W-Wahrnehmung [?] (нем.) - восприятие.

${ }^{9}$ Верхние отделы теменной доли. 
20.IV.

Опыт с Поляковым: Синдром правой премоторной области (1. Импульсивность с недостатком <расщепления> самосознания и 2. моторика: невозможность восприятия и повторения ритмов).

На правой стороне: NB!

\section{IV.}

1) Основная мысль: преморбидный уровень имеет \{значение\} в том смысле, что способность сохранять прежние следы и образовывать новые связи после ранения страдает по-разному; таким образом, у человека с низким преморбидом ранение может вызвать «нарушение» тех принципов, которые у другого сохраняются, не изза тяжести ранения, а из-за того, что у больных (А) эта функция идет в порядке воспитания новых связей, а у больного (Б) - в порядке воспроизведения прежних.

2) Ряд больных с отрицательными симптомами: ранение мягких тканей может вызвать скоропреходящую контузию данной системы... но очень быструю и полную реституцию (ср. Габдуллин, Агабеков и др. - реабилитация левой височной области).

3) Ранение может повести не только к выпадению, но и к ослаблению функции - типа Sehschwäche (cp. больной Калабеков) или Hörschwäche ${ }^{10}$ (cp. больные Габдуллин, Копало и др.).

\section{IV.}

Опыт с Дгантуевым - Универсальная аспонтанность (без лобной семиотики).

\section{IV.}

Нарушение смысла у лобных больных!

На правой стороне: СМЫСЛ И ЗНАЧЕНИЕ (лобные и задние поражения)

\section{Поездка в Москву}

\section{VI.42.}

Опыт с Моисеевым; беседа с \{О. П.\} Кауфман.

Межзональное взаимодействие. Каждая зона имеет свою специфическую функцию, но одновременно - вносит свой компонент в организацию работы других зон; так при теменных поражениях иначе (через островок?) начинает работать височная область; это выражается в невозможности схватить симультанные схемы акустических процессов и конкретно - невозможности схватывать звуковое строение слова, невозможности усваивать сложную структуру ритма (ср. || || || +; || | || | — не идет совсем!).

\footnotetext{
${ }^{10}$ Sehschwäche, Hörschwäche (нем.) - слабость зрения, слабость слуха.
} 
Отсюда — теменной синдром: нарушение симультанной схематизации в оптике (пространственное расположение), в грамматике, в счете; - то же и в акустике!!

На правой стороне: NB \{напротив слов Межзональное взаимодействие

22.VI.42.

1) Наблюдение больной Снеков: При теменных поражениях всякая задача, скрытая за вопросом, понимается (больной знает, что ему нужно ответить), но не схватывается структура вопроса.

На правой стороне: NB: Смысл и значение.

При лобных поражениях, коммоциях и общих деменциях - больной не схватывает смысл вопроса, т. е. задача, которую ему ставят, остается непонятной - и он обнаруживает тенденцию не отвечать на вопрос, а повторять вопрос, приближаясь к эхолалии!

На правой стороне: Ср. больной Давыдов!

2) Больной Петров (\{Э. С.\} Бейн) - Чистый височный синдром! Обучен усвоению звуков через букву.

3) Больные Барсук и особенно Мицкевич - резидуальное, устойчивое нарушение активных лобных систем. Лобная Abstimmung ${ }^{11}$ речевой функции - выражается в дезавтоматизации речи, ее аспонтанности, нарушении системы МЫСЛЬ $\rightarrow$ РЕЧЬ при достаточной сохранности системы W $\rightarrow$ РЕЧЬ; отсюда сохранность в назывании предметов и резкая амнезия в спонтанной речи.

На правой стороне: Лобная афазия!

Ср. Мицкевич! ср. Шингарев! ср. Карабанов! ср. Сычев!

4) Зозуля - синдром 37 поля (затылочно-височный синдром) - нарушение воспоминания слов без теменных расстройств.

На правой стороне: Затылочно-височный синдром?

5) Кашеев - Синдром $\mathrm{T}^{12}$ : нарушение акустико-речевой памяти при сохранности различения фонем.

На правой стороне: Синдром Т3 \{напротив слов: 5) Кашеев\}

23.VI.

1) Буйских - отрицательный случай афазии у латентного левши. Гипотеза ЛАТЕНТНОЙ амбивалентности полушарий и рецессивного наследования доминантности полушария: больной с наследственностью (родословная Буйск., см. рuс. 10).

11 Abstimmung (нем.) - настройка.

12 Синдром Т3 - синдром поражения нижней височной извилины. 
\{Пациент описан в книге «Травматическая афазия», случай 2 (Luria A. R., 1947, p. 37-38 / 1970, p. 63-64)\}.

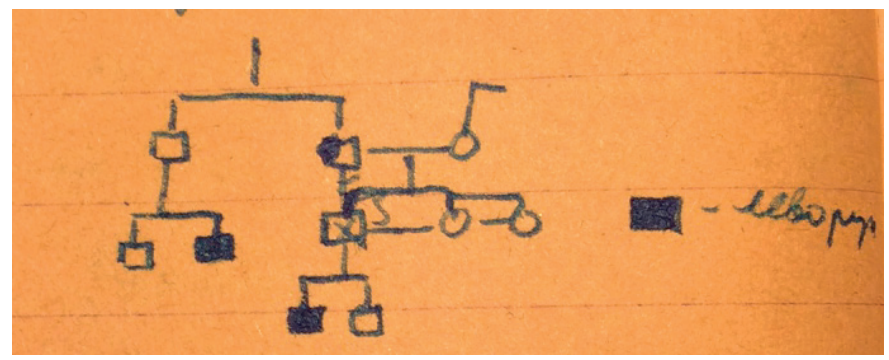

Puc. 10. Родословная больного Буйск.

2) Премоторный синдром: Востриков! Дюжев!

3) Давыдов: грубое нарушение левого полушария! Примитивность психики - на фоне относительной сохранности звуковой стороны речи.

4) Опыт с Никаноровым:

a) ступени фонематических затруднений в письме (задержки - перестановки звуков - замены).

б) Положение: При местных контузиях (без повреждения целостности мозга) - не синдром распада, а СИНДРОМ МЕСТНОЙ АСТЕНИЗАЦИИ!

- другая динамика структуры,

- другое течение,

- другой прогноз.

На правой стороне: Ср. Султанов! Ср. Блинников!

Тема: КЛИНИКА травматической афазии

(формы разрушения - форма астений)

\section{VII}

1) Опыт с премоторным синдромом П П $\Lambda^{13}$

I. Группа премоторных больных дает четкие и стойкие симптомы

II. Группа около-премоторных больных - нестойкие легко преодолеваемые симптомы

III. Группа премоторных, лобно-височных больных — может не давать симптомов

IV. Группа правых премоторных больных -??

2) Косроченко - распад строения сложных действий при лобном абсцессе.

\section{VII}

Опыт с Косроченко.

1) Лобные поражения - нарушение мотивации, вместо мотивов - полевые факторы, штампы.

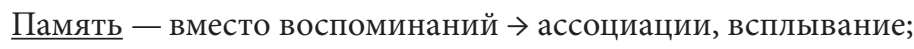

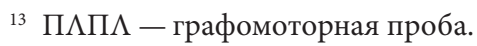


W. $\{$ восприятие $\}$ - в пределах впечатлений!

Понимание - только внешней ситуации, но не мотивов.

2) Восстановление - (компенсация); пути (а) через расчленение сложной инструкции на части, (б) через изменение контекста!!

На правой стороне:

$\{К$ 1)\} 1) Иллюстрация к Лобной главе (травматический материал).

2) С Бл. В. \{Зейгарник\} - значение/смысл!! Структура психических <процессов> при лобных поражениях

$\{$ K 2)\} NB. К теории компенсации (преодоления) лобных поражений!

\section{VII.}

1) Опыт с Куйбар. Псевдосемантический синдром при поражении левой височной доли.

Нарушение понимания грамматических структур - но с возможностью компенсации! (из-за невозможности удержания серии).

Нарушение устного счета - при сохранности письменного счета.

2) Опыт с Волковым: синдром Т3

Сохранность W. \{восприятия\} фонем, сохранность понимания слов (нет отчуждения), сохранность звукового анализа - при нарушении серийных рядов!!

На правой стороне: Псевдосемантическое (височное) расстройство.

T3!!

\section{VII.}

1) Опыт с Смирновым (ранение лобно-премоторной области).

а) Осколочная лейкотомия! ${ }^{14}$ Отделение всей лобной системы!! Отсюда - нарушение смысла - при сохранении значения.

b) На фоне общей аспонтанности - легкие нарушения премоторной речи.

NB: было задержано обратное развитие речи!!

На правой стороне: Эксперт военный Egas Monitz!! ${ }^{15}$

\section{VII.}

Опыт с Брозгаловым: Синдром Т2 (промежуточный между Т1 и Т3!!) $)^{16}$

На правой стороне: Т2

14 Лейкотомия (лоботомия) - рассечение белого вещества головного мозга.

${ }_{15}$ Egas Monitz (Эгаш Мониш) - португальский невролог, один из основателей современной психохирургии, разработал церебральную ангиографию, предложил хирургическую процедуру лейкотомии (современный термин лоботомия). Награжден в 1949 г. Нобелевской премией.

${ }^{16}$ Синдромы T1, Т2 и Т3 - синдромы поражения верхней, средней и нижней височных извилин. 


\section{VII.}

Новые афазики (общий просмотр).

NB: больной Школяр (правое лобное поражение у левши с отрицательной симптоматикой: латентный правша!!).

На правой стороне:

NB: Puc. 11. Генотипическая обусловленность доминантности (скрытый рецессивный правша!!).

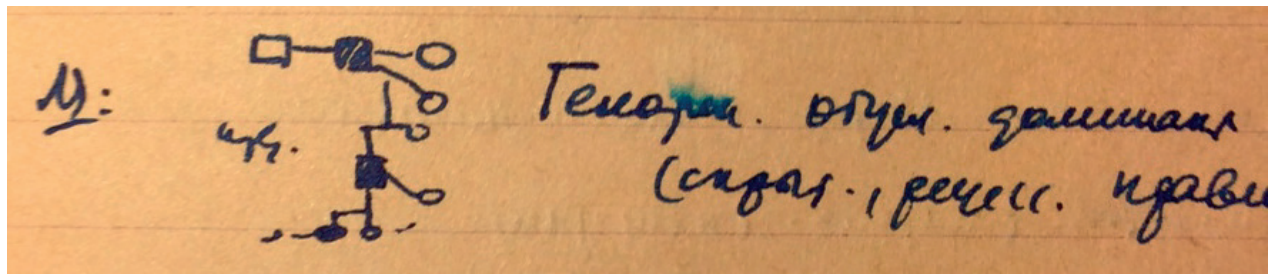

Puc. 11. Пациент Шк.

\section{VII.}

Просветов - грубый премоторный симптомокомплекс.

Новая сенсибилизированная проба (пересчет пальцев).

\section{Отъезд в Казань}

\section{VIII}

Опыт с больным Ивановым.

Неуклюжесть - теменная (экстра-пространственная)

- таламическая (постуральная)

- премоторная (динамическая)

\section{VIII}

Кулагин (\{с О. П.\} Кауфман). 1) Оптическая аграфия! 2) синдром синуса

\section{VIII}

1) Кертбат - обратное развитие синдрома Т2-3 дает выявление поражения сукцессивных процессов, нарушения акустического мнезиса и нарушения ударности.

2) Одинец - Т3 (полностью восстановлен).

На правой стороне: Динамические откаты ранений Т3

\section{VIII}

1) $\underline{\mathrm{Xарин}}$ - легкие симптомы лобной доли.

Пименов - отрицательный случай: ранение мягких тканей лобной доли без симптомов. 
2) Куличков - моторный аграмматизм с телеграфным стилем.

3) Берсенев - (больной Перельмана $)^{17}$. Нейро-динамический генез заикания у коммоционных больных. (Конфликт повышенной инерции возбуждения - с тенденцией к активной речи.)

На правой стороне:

NB
Нейро-динамические дисфазии!
у коммоционного больного
МИКСТА
\{со смешанной доминантностью\}

\section{VIII}

1) Гуряков. Отграничение афазии спереди (передне-височная афазия).

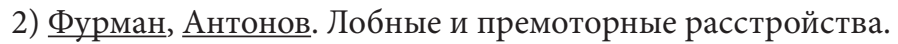

\section{VIII}

1) Бурсягин. Височная афазия. Нарушение повторения и называния слов.

2) Кондратенко. Лобная афазия (нарушение спонтанной речи).

\section{IX.}

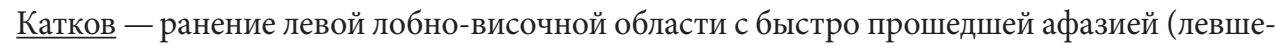
ство в роду, см. рuс. 12) \{см. «Травматическая афазия», случай 6 (Luria A. R., 1947, p. 39-40 / 1970, p. 67)\}.

На правой стороне:

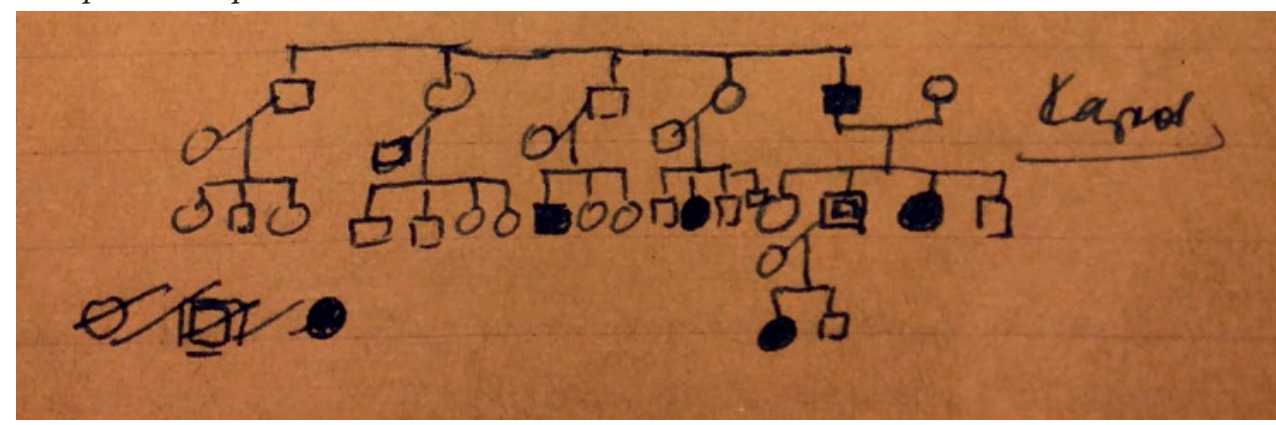

Puc. 12. Родословная пациента Катк.

17 Л. Б. Перельман - сотрудник госпиталя, невропатолог. Автор книги «Реактивная постконтузионная глухонемота, ее распознавание и лечение» (1943). 


\section{IX.}

Опыт с Карабановым (Бассин $)^{18}$. Невозможность <нрзб> подлинную конструкцию мелодии.

\section{IX}

1) Опыт с Карабановым - нарушение плавности в W. (восприятии) и мышлении (нарушение внутреннего поля).

2) Наблюдения над Макр <нрзб>. Нарушение произвольных процессов.

Сущность истерии: Обычно непроизвольные процессы становятся произвольными, а произвольное протекание процессов нарушается.

Уровни произвольности и уровни распада.

\section{IX}

Опыты с афазией.

Моторно-афазическое нарушение мышления (с О. П. Кауфман).

\section{IX}

1) Кондратенко. Ритмы. Нарушение автоматизации (премоторный синдром).

2) Просветов. Ритмы. Лобный синдром. Напряжение моторной установки в отсроченных действиях.

3) Суровцев, Саровец. Ритмы. Нарушение ритмов афферентного типа.

\section{X.42.}

Прохоров | Смысл и значение

Моисеев | при лобных поражениях

\section{X.42.}

1) Опыт с Sehschwäche ${ }^{19}$ при затылочном ранении (Захарченко): она «снимается» очками, т. е. «неясное зрение» пресбиопика ${ }^{20}$ перестает компенсироваться.

2) Опыт с Прохоровым: лобный больной: понимание смысла - счет (деление) - ритмы.

3) Опыт с Кубышкиным: компенсированное нарушение функций при поражении лобной доли у амбидекстра (см. puс. 13, вверху).

На правой стороне: NB: амбидекстрия!

${ }_{18}$ Ф. В. Бассин (1905-1992) - сотрудник госпиталя, психолог. Известный психолог и нейрофизиолог, специалист по психологии бессознательного, доктор медицинских наук. Входил в круг Л.С. Выготского. Один из инициаторов и организаторов Тбилисского симпозиума по проблеме бессознательного.

19 Sehschwäche (нем.) - слабость зрения.

${ }^{20}$ Пресбиопия («старческое зрение») - аномалия рефракции глаза, при которой человек не может рассмотреть мелкий шрифт или маленькие предметы на близком расстоянии. 
9.X.42. Надеждин: Левша с ранением правой премоторной зоны и соответствующим доминирующим гемисиндромом (рuс. 13, внизу) (на правой стороне).

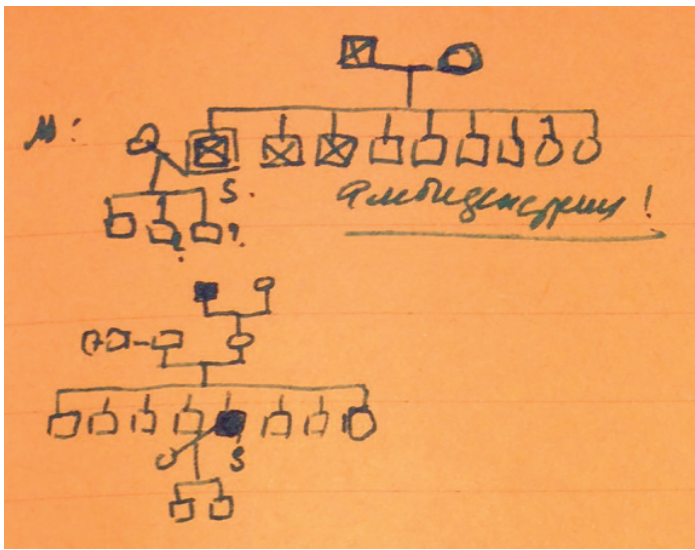

Рuc. 13. Родословные больных Куб. (вверху) и Над. (внизу)

\section{0-16.X.42.}

С О.П. Кауфман. Разработка вопросов моторной афазии.

1) Классификация моторных афазий (фазическая - денерваторная - динамическая)

2) Разные соотношения речи/мысли при них.

\section{X.42.}

1) Комаров. Грубая моторная афазия без семантических расстройств у больного с ранением левого полушария - при скрытом гене левшества дает очень незначительные семантические и <двигательные> расстройства - при грубых расстройствах моторной речи (рис. 14).

На правой стороне:

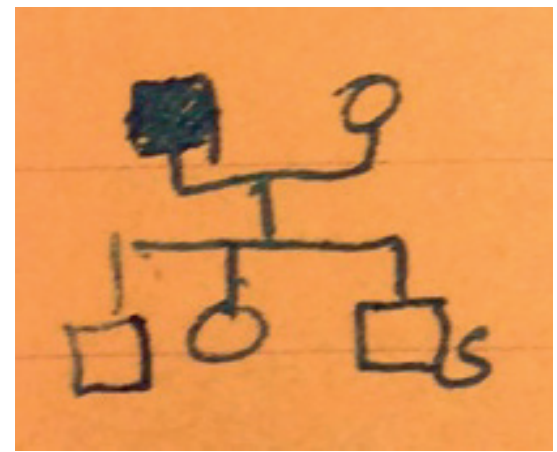

Puc. 14. Родословная Ком. 
2) Разбор моторных афазий: Классификация по

\begin{tabular}{|lccc}
\cline { 2 - 4 } длине & фазическая & денерваторная & динамическая \\
\cline { 2 - 4 } и & речь & речь & речь \\
толщине & письмо & - & - \\
& силлогич. эксп. $^{21}$ & - & - \\
\hline
\end{tabular}

22.X.

Саборов: аграмматизм [зачеркнуто]. Нарушение схемы фразы.

\section{X.}

Газдюк: Подкорково-коммоционный синдром (псевдо-паркинсонизм; с лобноподкорковым дефектом).

\section{X.}

1) Баранишин - синдром лобный (б).

2) Саборов - нарушение течения интеллектуальных процессов при лобной афазии.

28.X.

Саборов — невозможность удержания РЯДА.

\section{X.}

1) Саборов - Компенсация в серийных рядах

$=\mid-$ с осмышлением

| = - легко!!

\{Серия обведена треугольником, показывающим убывающую структуру серии. Возможно, это была проба выкладывания из палочек серии.\}

2) Правый лоб - Лейдест, Песчанов - Ритмы: оценка " как"' [т. е. оценка ритма «по 2» как «по 3»] - есть нарушение сензорной денервации (2 раза - один слабо).

На правой стороне: NB!! Нарушение оценки ритмов = явление нарушения сенсорной денервации!!

\section{XI.}

Еще случаи латентной леворукости! (Катков!)

\section{XI.}

1) Саборов - опыт с заучиванием стихотворения - распад структуры стихотворного ритма.

21 Силлогич. эксп. - по-видимому, имеются в виду тесты на понимание силлогизмов. Лурия использовал их для исследования мышления при лобных нарушениях или семантической афазии. 
2) Тогадев: тонкие остатки премоторной афазии («дом-стол-кот» \{проба Лурия на слухоречевую память $\}$ )

На правой стороне: NB

\section{XI.}

1) Саборов - лобный распад восприятия

2) Савельев - нарушение <нрзб> действий

\section{XI.}

1) Христов - височная афазия.

Новый сенсибилизированный метод исследования отчуждения слов (с выключением активной речи).

2) Симонов - моторная афазия с общим нарушением динамического фона.

\section{0-11.XI.}

Опыты с ритмами.

1) Опосредствование пространством (оптическая память) и речью.

\section{XI.}

Опыты с ритмами: опосредствование речевым образом «па-па» — «до-ро-га» у височных больных не дает никаких результатов (Бурсягин, Христов) [имеется в виду использование ударения в словах: в слове «па-па» ударение на первом слоге, в слове «до-рога» - на втором слоге].

\section{XI.}

1) Савельев | нарушение простых ритмов и

2) Шегалов | их опосредствование «пАпа» - «бородА» \{в слове «па-па» ударение на первом слоге, в слове «бо-ро-да» - на третьем слоге $\}$.

\section{(Конеи, записей 1942 г.)}

\section{Окончание следует...}

Original manuscript received July 05, 2020

Revised manuscript accepted July 27, 2020

First published online November 13, 2020

To cite this article: Akhutina, T. V., \& Pylaeva, N. M. (2020). Luria in Kisegach. Part 2. Lurian Journal, 1 (2). 101-146. doi: 10.15826/Lurian.2020.1.2.8 